\title{
Can Corporate Law on Groups Assist Groups to Effectively Address Climate Change?
}

\author{
A Cross-Jurisdictional Analysis of Barriers and Useful Domestic Corporate Law Approaches \\ Concerning Group Identification and Managing a Common Climate Change Policy
}

Tineke Lambooy \& Jelena Stamenkova van Rumpt*

\section{Introduction}

In the United Nations Framework Convention on Climate Change (UNFCCC) and the Kyoto Protocol to the UNFCCC (Kyoto Protocol), states and the EU have agreed to cooperate and to adopt climate change mitigation and adaptation programmes. ${ }^{1}$ Despite a growing number of climate change mitigation policies, in 2014, the Intergovernmental Panel on Climate Change (IPCC) proclaimed that the total anthropogenic greenhouse gas (GHG) emissions from 2000 to 2010 were the highest in human history and that "without additional efforts to reduce GHG emissions beyond those in place today, emissions growth is expected to persist driven by growth in global population and economic activities." The IPCC indicates with 'high confidence' that the baseline scenarios (those without additional mitigation) will result in global mean surface temperature increases in 2100 from $3.7^{\circ} \mathrm{C}$ to $4.8^{\circ} \mathrm{C}$ compared to pre-industrial levels. ${ }^{2}$ Only if atmospheric GHG concentrations would be stabilized at the equivalent of around $450 \mathrm{ppm}$ (430 -

Tineke Lambooy is Professor Corporate Law at Nyenrode Business University and Associate Professor Corporate Social Responsibility at Utrecht University. Jelena Stamenkova van Rumpt, LLM, is Advisor Responsible Investment at PGGM (Dutch Asset Manager for Pension Funds). We are grateful to Linn Anker-Sørensen, Aalt Colenbrander, Thijmen Nuninga and Muzaffer Eroglu for their contributions to this research project. The research for this paper closed by 20 November 2014.

1. The United Nations Framework Convention on Climate Change, New York, 9 May 1992. Article 7 of the UNFCCC establishes a 'Conference of Parties' (COP) overlooking the implementation of the Convention. For that purpose, the COP gathers in principle annually. See e.g.: the Bali Action Plan (COP13 in 2007), the Copenhagen Accord (COP15 in 2009), the Cancun Agreements (COP16 in 2010), and the Durban Decision (COP17 in 2011). The Kyoto Protocol to the United Nations Framework Convention on Climate Change, Kyoto, 11 December 1997.

2. This range is based on median climate response; however the range is $2.5^{\circ} \mathrm{C}$ to $7.8^{\circ} \mathrm{C}$ when including climate uncertainty. IPCC 2014, "Summary for Policymakers", in Climate Change 2014, pp. 6-8. The Summary for Policymakers has been approved line by line by member governments at the 12th Session of IPCC WG III in Berlin, Germany (7-11 April 2014). See also the full report: IPCC 2014, pp. 41, 113-114.
480) CO2eq by $2100,{ }^{3}$ is it 'likely' (> $66 \%$ chance) that a temperature change caused by anthropogenic $\mathrm{GHG}$ emissions can be kept to less than $2^{\circ} \mathrm{C}$ relative to preindustrial levels. ${ }^{4}$ The figure of $2^{\circ} \mathrm{C}$ is considered to be the tipping point for the aggravation of climate change. If exceeded, climate change consequences will dangerously affect mankind and ecological systems; consequences include flooding, hurricanes, droughts and unpredictable weather patterns, which will make people homeless, hamper normal life, threaten agricultural production and have an impact on business, as the reliability of supplies will be uncertain. ${ }^{5}$

There is international scientific and political consensus that climate change caused by anthropogenic emissions is a global challenge that urgently needs to be addressed more effectively. The IPCC emphasizes in this respect that both public and private actors have to play a role here:

Effective climate policy involves building institutions and capacity for governance. While there is strong evidence that a transition to a sustainable and equitable path is technically feasible, charting an effective and viable course for climate change mitigation is not merely a technical exercise. It will involve myriad and sequential decisions among states and civil society actors. $^{6}$

The focus of this article is on corporate law and how this body of law can contribute to supporting corporate actors in addressing climate change. As will be demonstrated in section 3 of this article, the international community expects from companies and in particular of cor-

3. A carbon concentration level of $450 \mathrm{ppm}$ entails that of every one million molecules, 450 molecules are carbon molecules.

4. IPCC 2014, "Summary for Policymakers", pp. 10-13, IPCC 2014, full report, pp. 113-114, 134. Cox 2014, p. 128.

5. As also becomes apparent in the various IPCC's reports. See e.g., Hegerl, G.C. et al., "Understanding and Attributing Climate Change", in IPCC 2007, Climate Change 2007, pp. 665-666, 696. IPCC 2014, p. 155 on 'risk': '“'Risk' refers to the potential for adverse effects on lives, livelihoods, health status, economic, social and cultural assets, services (including environmental), and infrastructure due to uncertain states of the world."

6. IPCC 2014, full report, pp. 41, 292, 297, and the chapters of this report that discuss sectoral mitigation pathways and measures. 
porate groups such as multinational enterprises $\left(\mathrm{MNEs}^{7}\right)$, that they contribute to combating climate change, by complying with pertinent environmental law norms and by adopting GHG emissions reduction programmes and policies. It is relevant to involve corporate groups in fighting climate change because a large part of the world trade, production and services is conducted through corporate groups, predominantly by a limited number of MNEs and their supply chains. ${ }^{8}$ These MNEs have an enormous influence on the behaviour of consumers, the development of the economy, domestic political decisions and laws, and the status quo of the environment. Their business and transport activities and many of the products that MNEs put into the market generate, in a direct way, a large part of the carbon dioxide (CO2) and other GHGs such as methane emissions in the world. ${ }^{9}$ Indirectly, MNEs cause other forms of environmental harm such as deforestation, which has an additional impact to climate change. ${ }^{10}$

If MNEs, as the most powerful private actors, would effectively address climate change in their core strategy and daily operations of their whole group, an enormous impact could be achieved on mitigating climate change. Reducing the risks of climate change will also have a positive impact on MNEs as many of them (might) suffer from climate change, too. That is, in various ways: in the short term, MNEs can expect many new regulations (restriction of GHG emissions allowances, carbon tax, etc.) that will force them to implement changes in their operations and to allocate budgets to comply therewith; in the long term, there will be physical impact to their business (a volatile climate will affect agricultural production for example).

There are voluntary activities undertaken by MNEs to measure ('carbon footprinting') and reduce GHG impacts on a group level pursuant to international private regulatory regimes; this will be discussed in section $3 .{ }^{11}$ However, we wished to acquire an insight into the role of corporate law in this matter. As corporate law provides the legal framework within which corporate groups are operating, one would expect corporate law to be capable of regulating corporate groups' governance and behaviour in a more systematic, structural and com-

7. In the climate change literature often referred to as 'TNCs', i.e. transnational companies.

8. See a detailed examination at UNCTAD, World Investment Report, 2011. See also Robe 2011, pp. 50-52. Depending on the definition used, there are between 800 and 63,000 MNEs in the world (see the UNCTAD study conducted in 2000, <http://unctad.org/en/Pages/ PressReleaseArchive.aspx?ReferenceDocld=2714>). See also Cafaggi 2011; Lambooy 2006; Stiglitz 2013.

9. IPCC 2014, "Summary for Policymakers", p. 6: "CO2 emissions from fossil fuel combustion and industrial processes contributed to about $78 \%$ of the total GHG emission increase from 1970 to 2010, with a similar percentage contribution for the period 2000-2010 (high confidence)"

10. IPCC 2000, Special report, Section 2.2.3.3. concerns deforestation; available at <www.ipcc.ch/ipccreports/sres/land_use/index.php?idp= 49>, accessed 24 January 2015.

11. For an analysis of international private regulatory regimes that are concerned with the sustainability policies of MNEs, see Lambooy 2010, pp. 227-276. pelling way than voluntary international initiatives can do. In this article, it will be enquired to what extent national corporate law systems and European corporate law provide possibilities to regulate corporate groups' governance and behaviour in a systematic, structural and compelling way in order to reduce the environmental damages.

\subsection{Methodology and Structural Overview}

The research that underlies this article is primarily based upon sources that were generated in the Sustainable Companies Project (SCP), an international research project that ran from 2010 till 2014, of which both Lambooy (the Netherlands) and Stamenkova Van Rumpt (Macedonia) were members. ${ }^{12}$ The aim of this project was to analyse the company laws of 24 jurisdictions worldwide to find out to what extent these laws support or obstruct companies in integrating environmental sustainability in their core business strategy, structures and activities. The representative of each participating jurisdiction prepared a Mapping Paper in accordance with a template, in which the main rules of corporate law and corporate governance of this representative's jurisdiction were presented; the law pertaining to corporate groups was one of the topics. ${ }^{13}$ The Mapping Papers were presented and discussed in several SCP expert meetings and academic conferences; the results of the research project that led to this article were exchanged with the other authors of the Mapping Papers in the final SCP conference in December 2013. A final draft of this article was also shared with all Mapping Papers authors in order to receive comments and updates in respect of any information presented in this article in respect of their jurisdictions.

The main research question addressed in this article is: in which way does corporate law mandate corporate groups to, and/or assist them in, adopting and implementing climate change programmes as expected by international policy makers? What legal barriers and/or best regulatory practices in realizing this goal can be identified? The research was conducted on the basis of an evaluative comparative law methodology. This entails that purely descriptive reports for all jurisdictions investigated are drawn up based on functional questions. This methodology allows the researchers to compare the function of the rules rather than their domestic terminology-laden appear-

12. The SCP was initiated and headed by professor Beate Sjafjell of Oslo University in Norway. Please visit the website of the SCP, available at: $<$ www.jus.uio.no/ifp/english/research/projects/sustainablecompanies/>, accessed 18 November 2014

13. Our research included several political and/or geographical regions, such as: the Nordic region (Denmark, Finland, Norway, Sweden), the EU (Germany, Hungary, Ireland, Spain, The Netherlands, Slovenia and the UK), other European states that are in the process of becoming a part of the EU (Macedonia, Albania and Turkey), Africa (Ghana and South Africa), Asia (China, India, Indonesia and Japan), North America (US and Canada), South America (Argentina and Brazil), and Oceania represented by Australia. Several of the Mapping Papers have been and will be published in the International and Comparative Corporate Law Journal. The others are on file with the authors. 
ance. ${ }^{14}$ The comparative synthesis thus created can subsequently be evaluated in the light of a predetermined criterion, allowing the researchers to indicate what approaches can be considered favourable in the light of that criterion (reference is made to the main research question). ${ }^{15}$

This article presents the findings as follows. In section 2, the object of study - i.e. corporate groups - will be further defined. As no single definition of the concept 'corporate group' exists, it is fruitful to carefully delineate on the basis of which conception of the corporate group the research was conducted. The authors' conception of the legal and theoretical background of corporate groups will be outlined.

In section 3, the criterion for evaluation will be further clarified. Since the criterion for evaluation refers to corporate law's ability to assist corporate groups in implementing climate change programmes, it will be enquired what it is exactly that is expected from corporate groups as regards climate change. This overview is created on the basis of an analysis of statements, official publications and (semi)legislation published by international policy makers.

In section 4 , the comparative synthesis will be presented. The comparison is limited to the jurisdictions assessed within the SCP. In order to increase accessibility, a general overview of general characteristics of the corporate laws of the jurisdictions assessed will be presented first. This will help the reader in understanding the subsequent synthesis central to this research. ${ }^{16}$ The central synthesis is based on three questions: (1) in which way does corporate law identify or define a corporate group? (2) does corporate law oblige or allow corporate groups to have a common policy to which all group companies must adhere? and (3) what instruments does corporate law offer to the central group management to implement a common policy? The answers to these questions are based on the information provided in the Mapping Papers that were drawn up in the context of the SCP.

In section 5 , the comparative synthesis will be evaluated in the light of the main research question pertaining to the ability of domestic corporate law systems to facilitate corporate groups in meeting the expectations identified in section 3. This section will first focus on the obstacles for achieving this goal. Next, the opportunities corporate law could offer are discussed in order to identify the better law approach. ${ }^{17}$ The 'best' approach is not found in one jurisdiction but is rather a hybrid of many solutions coupled with the authors' views. Section 6 contains the conclusion. The authors combine the better law approaches identified in section 4 and analysed in section 5. They present a combination of those approaches that will be capable of mandating and/or assisting corporate groups to adopt and effectively

14. Van Reenen 1995, p. 413; Zweigert \& Kötz 1998, p. 32; Örücü 2006, p. 32; Odekerk 2014, pp. 7-8.

15. Van Reenen 1995, p. 413; Odekerk 2014, pp. 33-35.

16. For a similar approach, see Vandekerckhove 2007, p. 27

17. Cf. De Boer 1992, pp. 39-40, citing Zweigert 1960, pp. 193-200. implement environmental policy goals concerning combating global climate change.

The subject of accountability and to what extent corporate groups must publish information about their environmental policies is dealt with by Charlotte Villiers and Jukka Mähönen in a similar way as in this article and making use of the same data base, ${ }^{18}$ and this subject will therefore not be addressed here. The subject of liability of corporate groups for environmental harm caused by their operations is dealt with by Linn Anker-Sørensen in this issue of Dovensmith Quarterly also utilizing the same data base. ${ }^{19}$

\section{Corporate Groups - Defining the Object of the Study}

Many attempts have been made to define a multinational company. For example, a widely supported definition was presented by the United Nations Conference on Trade and Development (UNCTAD):

[a] transnational corporation (TNC) is generally regarded as an enterprise comprising entities in more than one country which operate under a system of decision-making that permits coherent policies and a common strategy. The entities are so linked, by ownership or otherwise, that one or more of them may be able to exercise a significant influence over the others and, in particular, to share knowledge, resources and responsibilities with the others. ${ }^{20}$

Conducting international business operations through corporate groups is popular. ${ }^{21}$ The reasoning behind group formation is multiple. A first reason is that enterprises are expanding organically through acquiring other companies and by setting up businesses in other countries. A motive to incorporate a local subsidiary in a country in which the group intends to do business is to create local presence. That might be useful for obtaining licences, and for creating a relationship with local tax authorities, banks and customers. Groups also incorporate new legal entities in various countries in order to

18. Mähönen \& Villiers 2015.

19. Anker-Sørensen 2014, pp. 3-4.

20. UNCTAD, Transnational Corporations Statistics, available at: <www unctad.org/Templates/Page.asp?intltemID=3159\&lang=1>, accessed 18 November 2014. Compare the OECD definition which is less distinct: OECD, OECD Guidelines for Multinational Enterprises, 2011, section I, par. 4

21. See for a more detailed examination Dunning \& Lundan 2008 and Caves 2007. 
benefit from the differences in national tax laws. ${ }^{22}$ Another reason for group forming is to create liability shields by incorporating every new part of the business or new venture into a new legal entity. Other parts of the group will then be protected from any liability connected with the new business as they will legally only be regarded as shareholder or as a group company (see the article of Anker-Sørensen in this issue on the subject of limited liability). Groups often have complicated legal structures and consist of hundreds of companies.

The existence of corporate groups is independent from applicable corporate law systems and geographical region. All Mapping Papers of the covered jurisdictions indicate that corporate groups operate in their jurisdictions, i.e. groups consisting of domestic legal entities but also groups formed by legal entities of different nationalities. Groups exist all across the world: both in jurisdictions with a civil law tradition and jurisdictions with a common law tradition and both in developed economies and emerging economies. ${ }^{23}$

\subsection{Legal Structure and Governance}

Groups appear with different ownership models: the ultimate owner of the group's holding company could be a family, ${ }^{24}$ an institutional investor or a group of investors; there could also be a dispersed ownership structure, e.g. in the case that the group is listed on a stock exchange. Subsidiary companies are often 100\% owned by the parent company or sub-holding companies, but sometimes legal entities that are not $100 \%$ owned also belong to a group. Group entities are often limited liability companies, but at times, groups also include other forms of legal entities such as partnerships, coops and trusts.

A group structure could be organized around a parent company and subsidiaries, often referred to as 'company law formation'. ${ }^{25}$ Another way of creating a (international) group is if one (or more) company enters into contractual relationships with independent companies. We will refer to such a situation as a 'corporate network'

22. There are recent initiatives by EU Commission and the OECD to tackle "agressive tax planning". See European Commission, An Action Plan to Strengthen the Fight Against Tax Fraud and Tax Evasion, COM (2012)/ 0722 final, including two recommendations. See also: OECD, Tackling Aggressive Tax Planning Through Improved Transparency and Disclosure, February 2011, OECD, Corporate Loss Utilisation Through Aggressive Tax Planning, August 2011, OECD, Hybrid Mismatch Arrangements, March 2012, OECD, Addressing Base Erosion and Profit Shifting, February 2013. There has been an increased attention internationally for corporate tax affairs, see e.g. the attention it received at the G20: G20, Policy Statement - Strengthening tax systems, 2014.

23. Some Mapping Papers mentioned the existence of corporate groups explicitly. See e.g.: Turkish Mapping Paper, §C.1 at pp. 47-48, Danish Mapping Paper, §1.2.4.1 at p. 7; Norwegian Mapping Paper, §1.2 at p. 3, Irish Mapping Maper, §1.2, p. 13. Other Mapping Papers show implicitly that corporate groups exist. See e.g.: German Mapping Paper, $\S$, at pp. 33-34, UK Mapping Paper, §1.1 at pp. 6-7, US Mapping Paper, §6.1 at p. 33, South African Mapping Paper, §C.5 at p. 51.

24. This is often the case in Canada; see the Canadian Mapping Paper, §॥ at pp. 9-10.

25. See for more details: Muchlinski 2007. For example, see the top legal structure of Unilever (simplified), accessible at: <www.unilever.com/ investorrelations/shareholder_info/understanding_nvplc_shares/index. aspx>, accessed 19 November 2014 or 'network group'. Examples are franchising and supply chain networks. ${ }^{26}$ As these networks are formed through contracts that are according to the Mapping Papers ordinarily not regulated in corporate law, we will not elaborate on these types of groups in this article. Combining the two approaches is also being done: corporate groups established through company law formation can enter into contractual relationships with other companies and groups.

In a group, a single company's operational decisions might be influenced by another company's operational policies. A subsidiary company might have to follow orders of the parent company. A franchisee company might also be obliged pursuant to contracts to follow the business policies and instructions of the franchisor. ${ }^{27}$

In practice, the legal structure of a corporate group may differ from the organizational structure because the way in which the international business is organized often follows another logic, e.g. per geographical region or product line. ${ }^{28}$ By organization, we mean the day-to-day model in which the business takes place: who gives instructions to whom and who reports financial and other results to whom?

\section{Which Role Is Expected of Corporate Groups towards Sustainability and, in Particular, Climate Change by International Policy Makers?}

\subsection{EU Policy Documents on Corporate Social} Responsibility

The European Commission has put forward a definition of Corporate Social Responsibility (CSR) in its Communication entitled 'A renemed EU strategy 2011-14 for Corporate Social Responsibility' (2011). ${ }^{29}$ This definition has been widely supported and repeated. According to the Commission, CSR is:

the responsibility of enterprises for their impacts on society. Respect for applicable legislation, and for collective agreements between social partners, is a prerequisite for meeting that responsibility. To fully meet their corporate social responsibility, enterprises should have in place a process to integrate social, environmental, ethical, human rights and consumer concerns

26. See further: Muzaffer 2008. We also refer to Cafaggi 2011 and Weitzenboeck 2012

27. For further reading, please see McKern 2003.

28. Lambooy et al. 2013; Lambooy, Diepeveen \& van 't Foort 2013. See also: the Canadian Mapping Paper, §ll at p. 10, and Osgood, Rue \& Kho 2013.

29. See the policy document: European Commission, A Renewed EU Strategy 2011-14 for Corporate Social Responsibility, $\operatorname{COM(2011)~} 681$ final. 
into their business operations and core strategy in close collaboration with their stakeholders, with the aim of:

- maximising the creation of shared value for their owners/shareholders and for their other stakeholders and society at large;

- identifying, preventing and mitigating their possible adverse impacts. [italics added] ${ }^{30}$

Interestingly, the Commission refers to enterprises rather than to companies, thereby implying that it also addresses groups of companies that act as an enterprise. Another noticeable element in the definition concerns the statement that enterprises must set up a process to make social, environmental, ethical, human rights and consumer concerns part of the core strategy. That could be understood in a way that the central management of the enterprise has to address CSR, because only the central management develops the core strategy and can introduce new processes throughout the whole group. For instance, in respect of the CSR issue of climate change, which is one of the possible adverse impacts of business activities as referred to by the Commission, this could mean that the central group management formulates a group strategy to reduce any negative impacts resulting from the business operations by the group companies, regardless of each of those companies' nationality, and manages the process of implementation. The Commission's definition continues by stating:

The complexity of that process will depend on factors such as the size of the enterprise and the nature of its operations. (...) To maximise the creation of shared value, enterprises are encouraged to adopt a longterm, strategic approach to CSR, and to explore the opportunities for developing innovative products, services and business models that contribute to societal wellbeing and lead to higher quality and more productive jobs.

To identify, prevent and mitigate their possible adverse impacts, large enterprises, and enterprises at particular risk of having such impacts, are encouraged to carry out risk-based due diligence, including through their supply chains. [emphasis added] $]^{31}$

In this part of the definition, the Commission promotes a long-term, strategic approach to CSR and a risk-based due diligence that includes supply chains. This suggests that the Commission expects the central management of a corporate group to develop CSR strategies with a longer horizon than the next general meeting of shareholders and that such a strategy should include the objective to conduct impact assessments that cover not only all group companies' activities but also the activities of other entities that make up the supply chain. It appears that the Commission expects MNEs to use their bargaining power and to exert their influence in order to address any adverse impacts of all activities in the supply chain.

30. European Commission, $\operatorname{COM}(2011) 681$ final, supra note 29, p. 6

31. European Commission, $\operatorname{COM(2011)~} 681$ final, supra note 29, p. 6.
The last part of the Commission's definition of CSR reads:

According to these principles and guidelines, CSR at least covers human rights, labour and employment practices (such as training, diversity, gender equality and employee health and well-being), environmental issues (such as biodiversity, climate change, resource efficiency, life-cycle assessment and pollution prevention), and combating bribery and corruption. (...) The promotion of social and environmental responsibility through the supply-chain, and the disclosure of nonfinancial information, are recognised as important cross-cutting issues. [emphasis added] ${ }^{32}$

In this last part, the Commission explicitly identifies $\mathrm{cli}$ mate change as one of the CSR themes that require a group strategy, and for which responsibility must be taken. The Commission even recognizes that an enterprise can promote environmental responsibility through the supply chain. Significantly, the Commission points at the importance of the disclosure of non-financial information.

In regard to EU corporate law, it is pointed out that although the Commission advocates that companies and corporate groups practise CSR and act on environmental challenges such as climate change, none of the EU Corporate Law Directives addresses the issue of climate change. Within the EU legal framework, the climate change challenge is only regulated in the context of environmental law; i.e. EU Directive 2003/87/EC established a scheme for GHG emission allowance trading for companies in order to promote reductions of GHG emissions (EU GHG Emissions Directive), called the EU Emission Trade System (ETS). ${ }^{33}$ However, this piece of environmental law, implemented by the EU Member States in their national environmental laws, only applies to companies, or more precisely to 'establishments', that are employing industrial activities on the national territory. ${ }^{34}$ Hence, this legislation does not regulate at group level how an MNE should manage its worldwide climate change impact. Furthermore, there is no clear link between the EU GHG Emissions Directive and corporate reporting, i.e. the first one does not require corporate groups to report about group climate

32. European Commission, $\operatorname{COM}(2011) 681$ final, supra note 29, p. 7

33. This Directive was amended in 2009: Council Directive (EC) 2009/29 amending Directive 2003/87/EC so as to improve and extend the greenhouse gas emission allowance trading scheme of the Community [2009], OJ L 140/63. Reference is also made to the UK Mapping Paper, $\S 1.3$ at p. 14: “The Climate Change Act 2008 sets a legally binding target of an $80 \%$ reduction in certain greenhouse gases by 2050 through domestic and international actions with intermediate targets for 2020; establishes a carbon budgeting system to cap emissions over 5 year periods; creates a Committee on Climate Change; and includes measures on emissions trading schemes, biofuels, household waste and single-use carrier bags." In the Netherlands, the EU ETS system is implemented in Chapter 16 of the Wet Milieubeheer (Act on Environmental Management); Dutch Mapping Paper, §1.1 at p. 6

34. Critical about the ability of the ETS to solely tackle the problem of GHG-emissions are Böhringer 2014, pp. 8-15; Vlachou 2013, pp. 17-24 and Ellerman \& Buchner 2007, p. 84. 
change programmes in their consolidated annual reports. The same comments can be made concerning other regulatory systems that have introduced voluntary or mandatory carbon trade or established a carbon tax, e.g. in Japan and Australia. ${ }^{35}$

\subsection{EU Directive on Non-Financial Disclosure by Corporate Groups and the Link with Corporate Climate Change Programmes}

Recent studies performed at the request of the EU Commission showed that there is a lack of reliable and comparable CSR disclosures by large companies and groups in the EU and that this is caused by market failure and regulatory failure. ${ }^{36}$ For that reason, the Commission proposed a new Directive aimed at enhancing the transparency concerning the strategy and impacts of large companies and groups in regard to all categories of social and environmental matters, including the challenge of climate change. In October 2014, the "Directive of the European Parliament and of the Council amending Directive 2013/34/EU as regards disclosure of nonfinancial and diversity information by certain large undertakings and groups" (EU Directive on non-financial information) was adopted. ${ }^{37}$ This Directive amends the Accounting Directive ${ }^{38}$ with the aim of integrating

35. The Japanese Mapping Paper reveals in $\$ 11(b)$ at p. 7 that the Tokyo metropolitan government and the Ministry of the Environment have created voluntary trading schemes. The law for cap and trade has not yet been passed (at the closing date of the Mapping Paper) but the industry has shown an interest in emission cap and trade. The Australian Mapping Paper informs in $\S$ at p. 2 that the government ratified the Kyoto Protocol in December 2007. The proposal to enact a carbon tax (both for the industry and households) was at the centre of a heated political debate. The 'Clean Energy Bill' became effective on 1 July 2012. A comprehensive emission trading scheme has not been adopted yet. For more information about the Clean Energy Bill of 2011, please see Peel 2014, pp. 432-450.

36. See European Commission, Commission staff working document accompanying the document Proposal for a Directive of the European Parliament and of The Council as regards disclosure of non-financial and diversity information by certain large companies and groups Impact assessment, SWD/2013/127, pp. 11-12. On the one hand, the market itself does not offer sufficient (financial) incentives to companies to prepare detailed CSR disclosures and, on the other hand, the current EU non-financial reporting obligation as introduced by the Modernisation Directive is perceived by most stakeholders as ineffective, mainly due to design weaknesses. In particular: the filters provided in the current wording (information to be disclosed only 'where appropriate' and 'to the extent necessary for an understanding of the company's development, performance or position') fail to provide a clear legal obligation. This has led the majority of companies to consider the current reporting regime as purely 'voluntary'.

37. Council Directive (EC) 2014/95 amending Directive 2013/34/EU as regards disclosure of non-financial and diversity information by certain large undertakings and groups [2014], OJ L 330/1.

38. The Accounting Directives, i.e. the Fourth Council Directive (EEC) $78 / 660$ on the annual accounts of certain types of companies [1978], OJ L 222/11, and the Seventh Council Directive (EEC) 83/349 on consolidated accounts [1983], OJ L 193, were amended in 2003 by Council Directive (EC) 2003/51 amending Directives 78/660/EEC, 83/349/EEC, $86 / 635 / E E C$ and $91 / 674 / E E C$ on the annual and consolidated accounts of certain types of companies, banks and other financial institutions and insurance undertakings [2003], OJ L 178/16. In 2013, they were replaced by Council Directive (EC) 2013/34 on the annual financial statements, consolidated financial statements and related reports of certain types of undertakings, amending Directive 2006/43/EC of the European Parliament and of the Council and repealing Council Directives 78/660/EEC and 83/349/EEC [2013], OJ L 182/19. social and environmental concerns into corporate groups' business operation and strategy. ${ }^{39}$ Articles 1(1) and 1(3) stipulate that large companies and groups must include in their annual management report, respectively annual consolidated management report, the following information:

(...) a non-financial statement containing information to the extent necessary for an understanding of the undertaking's [group's] development, performance, position and impact of its activity, relating to, as a minimum, environmental, social and employee matters, respect for human rights, anti-corruption and bribery matters, including:

(...)

(b) a description of the policies pursued by the undertaking [group] in relation to those matters, including due diligence processes implemented;

(c) the outcome of those policies;

(d) the principal risks related to those matters linked to the undertaking's [group's] operations including, where relevant and proportionate, its business relationships, products or services which are likely to cause adverse impacts in those areas, and how the undertaking [group] manages those risks; [emphasis added $]^{40}$

Hence, for example in respect of the issue of climate change, a large company or a group must share through its annual (consolidated) management report its policies on reducing climate change, the risks related to climate change, and the way in which the policies have been implemented as well as the actual data collected regarding the group's performance.

The Commission explains in the accompanying policy documents that (1) "more transparency and better quality of information on companies' environmental performance could increase the level of environmental awareness and, as a consequence, contribute to better environmental performance" [emphasis added] and (2) "the requirement to disclose material issues related to environmental policies and risk-management aspects would also introduce a forward looking element in the

39. Council Directive (EC) 2014/95, supra note 37, Preamble, para. 3.

40. Large companies are defined as: "Large undertakings which are publicinterest entities exceeding on their balance sheet dates the criterion of the average number of 500 employees during the financial year". Public-interest refers to listed companies. This is also mentioned in the Preamble, para. 6 of Council Directive (EC) 2014/95. We also refer to the minutes of an earlier Meeting of the 'Expert Group on Non-Financial Disclosure by Companies': "non-financial disclosures should cover at least the following elements: the company's assessment of risks and opportunities relevant to its particular business; its policy on identifying, assessing and managing key risk and opportunities, and how this policy is integrated with the overall business strategy; how this policy is implemented in its operational activities (including systems and processes); its results and forward-looking expectations; its measurement methodology; whether the report is based on internationally recognised standards, guidelines or principles and if so, which ones. Some experts added that a report should also include statements concerning the inclusion of stakeholders, due diligence, as well as monetary and non-monetary incentives", see European Commission, Expert Group on Non-Financial Disclosure by Companies - Meeting Report, 30 September 2011, p. 2. 
non-financial statements". ${ }^{41}$ Arguably, collecting nonfinancial data in the context of reporting is one of the ways in which to enhance the capacity of the management to manage and deal with issues and problems:

'Only what gets measured gets managed' is an expression commonly used in respect to financial information. Extending such reasoning to non-financial information, evidence suggests that the lack of transparency has a direct impact on non-financial performance: if non-financial aspects are not measured, they cannot be properly managed. ${ }^{42}$

This point of view was confirmed in the public consultations organized by the Commission and consolidated research. ${ }^{43}$ Companies that already disclose non-financial information underlined the benefits brought by non-financial reporting in terms of better integration of non-financial performance into their business operations and strategy. Others indicated that the EU should provide uniform rules with regard to non-financial reporting, in order to prevent divergent requirements in EU Member States. ${ }^{44}$

\subsection{Corporate Groups and Climate Change: Views of OECD, UN, CDP and WBCSD}

A comparable view with the EU Commission's view is embodied in the 2011 OECD Guidelines for Multinational Enterprises (OECD Guidelines). They avow the expectation that an MNE integrates CSR goals in its
41. European Commission, SWD/2013/0127 final, supra note 36, p. 41. European Commission, Public Consultation on Disclosure of NonFinancial Information by Companies, 2010, pp. 3-4.

42. European Commission, SWD/2013/0127 final, supra note 36, p. 18. See also: Tonello 2011; loannou \& Serafeim 2013; Porter and Kramer 2006; PricewaterhouseCoopers (PwC) 2009, p. 1; European Commission, Expert Group on Non-Financial Disclosure by Companies - First Meeting, 11 July 2011; UNCTAD, Investment and Enterprise Responsibility Review, 2011, p. 60. A study by the Centre for Strategy \& Evaluation Services (CSES) shows, for instance, that only a small minority of companies includes any reference to their sustainability performance in the context of their Annual General Meeting (AGM) and that some companies do not have any feedback mechanisms to boards or senior management on non-financial issues. See CSES, Disclosure of nonfinancial information by Companies, 2011, p. 12. Another subject is the correlation between improving the quality and quantity of nonfinancial disclosures on the one hand and financial performance on the other. A growing body of academic research indicates a positive correlation. Various studies indicate that front-running companies on sustainability issues tend to outperform their competitors in financial terms. This seems particularly the case when looking at the results produced over the medium (3-5 years) to long term (5-10 years). See Bauer \& Hann 2010; Iannou \& Serafeim 2013 and Tonello 2011. For a review of existing research see Fulton, Kahn \& Sharples 2012.

43. European Commission, Summary Report Of The Responses Received to the Public Consultation on Disclosure of Non-Financial Information by Companies, April 2011, p. 8.

44. European Commission, SWD/2013/0127 final, supra note 36, p. 45. influence the partners in the supply chain to also implement sustainability goals in the daily operations. ${ }^{45}$

The UN has exposed similar views. For example, by stimulating that the private sector comply with the UN Global Compact Principles (UNGCP), ${ }^{46}$ commit to joining the Global Compact 'Caring for Climate' programme $^{47}$ and participate in the Carbon Disclosure Project (CDP). ${ }^{48}$ Furthermore, the UN stipulates in Millennium Development Goal (MDG) No. 8 that private actors have a role to play in the realization of the MDGs through building partnerships with governments, communities, NGOs and others. ${ }^{49}$ MDG No. 7 focuses on environmental sustainability. It is mentioned that global CO2 emissions have increased by more than 50 per cent since $1990 .{ }^{50}$

Noteworthy is also the World Business Council for Sustainable Development (WBCSD). This international non-governmental organization is forming alliances with MNEs that commit to achieving concrete goals in respect of climate change mitigation and other CSR objectives. ${ }^{51}$

45. The OECD Guidelines, supra note 20, emphasize the need for more transparency and responsibility of MNEs toward managing their impact as well as the impact which they have through their business relations and supply chains on environmental and social issues, including GHG emissions reporting and monitoring. The Guidelines also recommend companies to disclose information about topics with regard to which reporting standards are still evolving, e.g. social, environmental and risk reporting. GHG emissions are an example hereof, as the scope of their monitoring is expanding. Monitoring concerns various emissions, i.e. direct and indirect, current and future, corporate and product emissions; see OECD 2011, supra note 20, section III, para. 33. The Guidelines can be considered soft law.

46. The UNGC ask companies to support and enact within their sphere of impact a set of core principles in the area of human rights, labour standards, environment and anti-corruption. The role of business towards climate change is one of the areas of attention.

47. Caring for Climate and UNEP, Rio+20 Corporate Sustainability Forum Joint Commitment for Climate Transparency and Disclosure; <http:// caringforclimate.org/wp-content/uploads/Joint_Commitment_

Statement.pdf>; accessed 15 January 2015.

48. The CDP works with companies and institutional investors to reduce companies' GHG emissions and mitigate climate change risk: "For over a decade CDP has worked to tackle climate change... We believe that systemic change - a real transformation of the global economic system - is required if we are to achieve the scale of change that will limit global warming and prevent catastrophic climate change... The CDP system has helped move climate change and energy efficiency onto the business radar and into mainstream business thinking."; <www. cdproject.net/en-US/Programmes/Pages/CDP-Investors.aspx>, accessed 18 November 2014.

49. See the MDG website, available at: <www.un.org/millenniumgoals/ global.shtml>, accessed 18 November 2014.

50. MDG No. 7 regards ensuring environmental sustainability. Getting to this goal takes many actions on different levels and lowering GHG emissions is one of the many, see the MDG website, available at: <www.un. org/millenniumgoals/environ.shtml>, accessed 18 November 2014.

51. In 2009, 29 WBCSD members (all MNEs) produced 'Vision 2050', 'a report that plots a pathway to a world in which 9 billion people live well and within the boundaries of the planet'. Taking Vision 2050 one step further to deliver tangible outcomes, the WBCSD is developing a framework for action called 'From Vision 2050 to Action 2020' - 'Action 2020 ' for short - 'to rally the efforts of business to deliver on the economic, environmental and social promises made in Vision 2050'. Action 2020 is one of the WBCSD's flagship projects and is supported by 15 co-chair members and 23 core members, see the Action 2020 website, available at: <www.wbcsd.org/action2020.aspx>, accessed 18 November 2014. 
These soft law and private regulation initiatives provide generally accepted, non-legally binding guidance for companies on how to deal with CSR and sustainability aspects, including climate change. ${ }^{52}$

Furthermore, reference is made to the ILO Tri-partite Declaration of Principles on Multinational Enterprises and Social Policy, the ISO 26000 Standard on Social Responsibility and the UN Guiding Principles on Business and Human Rights, which also set CSR standards for business conduct.

In respect of reporting and creating transparency about corporate conduct, including climate change programmes, the Global Reporting Initiative (GRI) is presently considered the most widely adopted and used reporting framework; it offers indicators on how to report on climate change programmes. Reference is also made to the International Integrated Reporting Council (IIRC), an organization dedicated to the creation of a global framework for integrated reporting, meaning that financial, environmental (including climate change issues), social and governance information are included in a single corporate report. ${ }^{53}$

\subsection{Presumptions That Underlie the Expectations}

The analysis in this section demonstrates that international organizations such as the EU, the UN and the OECD expect from corporate groups that they apply a pro-active and structured approach in respect of mitigating climate change by adopting group-based programmes, implementing these, measuring the quantitative results and sharing these in annual reports. These expectations seem to presuppose that corporate groups are well identified, that all group members follow a common strategy and that all of them agree with measuring the results of the implementation of this strategy, sharing these results with the other group companies and disclosing them in joint annual reports.

In the light of the above, an effective climate change programme of an MNE would appear to entail, firstly, designing the group's strategy on mitigating the impact on climate change. This strategy should clearly indicate which companies and entities form part of the group. The strategy has to clarify if and to what extent GHG emissions of the supply chain of the group will also be included in the group calculations, and which methodology is to be followed in the calculations. ${ }^{54}$ Furthermore, the strategy should indicate which reduction targets the group is pursuing and the timeframe for real-

52. For compare on international CSR private regulatory regimes, see Lambooy 2010, pp. 227-276.

53. European Commission, SWD/2013/0127 final, supra note 36, p. 7. For a good overview of other organizations that are working on sustainability related frameworks, see pp. 55-57. See also United Nations Environment Partners (UNEP), KPMG \& GRI, Carrots and Sticks: Promoting Transparency and Sustainability: An update on trends in Voluntary and Mandatory Approaches to Sustainability Reporting, 2010.

54. Dragomir 2012, pp. 222-237, demonstrates that it is impossible to compare the GHG data disclosed by five European oil \& gas and energy companies and that even the data disclosed by the same enterprise in the course of several subsequent years are incomparable. izing the targets and include instructions to all group companies on what they have to do to realize their share of the targets. Secondly, central management should be able to enforce the implementation of the strategy on each of the group companies and to collect reliable data from all group companies to determine the group's total GHG emissions. ${ }^{55}$

In this article, it will be examined if and to what extent current corporate law on groups in the jurisdictions covered by the Mapping Papers supports the expectations of the EU Commission and international organizations regarding MNEs' conduct concerning designing and implementing climate change mitigation policies and the underlying presumptions. There are in particular three issues that need to be assessed under corporate law: (1) what are the parameters corporate law provides to identify the group - where are the boundaries? (2) does corporate law oblige, or facilitate, that a group has a common strategy? and (3) does corporate law support the central management in enforcing the group strategy upon the group companies - i.e. an issue of control and governance - and in collecting the required data from the group companies?

Section 4 contains the cross-jurisdictional analysis that will address these questions from national corporate law perspectives, based on the Mapping Papers.

\section{The Regulation of Corporate Groups in the Corporate Laws of the Covered Jurisdictions}

Corporate groups can be identified in various ways: corporate law is one approach, in particular with a view to defining groups which must publish consolidated financial accounts, but also tax law, competition law, bankruptcy law and co-determination law recognize groups and have ways of identifying them. As this article focuses on corporate law and corporate governance, exploring the other legal approaches falls beyond the scope. First, in section 4.1, general characteristics of national corporate law approaches to groups will be stipulated. Next, in section 4.2, differences and similarities among the assessed jurisdictions are examined in order to find out how parent-subsidiary relationships are defined in corporate law and when they are deemed to establish a group. Subsequently, in sections 4.3 and 4.4, we will assess whether the national corporate law systems regulate (1) that a group can have a common strategy and (2) what the rights and duties of the central management are in enforcing the group strategy upon the group companies and in collecting data. Interesting national law examples will be shared because they demonstrate best

55. Also referred to as the 'CO2 footprint', or the 'GHG footprint' if the measurements also include data on GHG emissions other than $\mathrm{CO} 2$ 
practices in regulatory approaches and can serve as an inspiration for other jurisdictions.

\subsection{General Characteristics of National} Corporate Law Approaches to Groups ${ }^{56}$

\subsubsection{Groups and Group Law: A Variety in Regulatory Approaches}

Our research revealed that although in general a definition of a group is hard to find in the company laws reviewed, corporate law as a rule includes references to corporate groups. However, the level of regulation differs greatly. In some jurisdictions, group law is a special division of corporate law (e.g. Germany, Slovenia and Hungary), in other jurisdictions, corporate law just contains a few provisions that directly or indirectly refer to corporate groups. Most jurisdictions just define what constitutes an affiliated company and/or a subsidiary company. Whereas they regulate the subject of consolidated financial statements, the regulation of other issues concerning groups are mainly left to general rules and principles. A group is usually identified as a combination of companies that are affiliated with each other either through shareholdings or another form of control, such as by contracts (economic ties), by the parent company over the group companies. In section 4.2 , we will identify what the term control entails in this context. Interestingly, in Brazil, groups need to register with a regulatory body. Registration requirements concerning group forming were also discovered in Hungarian and

\subsubsection{Consolidated Accounting by Groups}

Among all jurisdictions, we found that corporate groups can or must present consolidated accounts so that the shareholders, financiers, creditors and other stakeholders of the group companies can acquire an understanding of the group's activities and financial position. EU jurisdictions follow EU law; the law of other jurisdictions refers often to international accounting standards. ${ }^{57}$

\subsubsection{Domestic Application of Corporate Lam}

Another common principle is that domestic corporate law only governs those companies that are incorporated in that jurisdiction. ${ }^{58}$ Hence, for example, in the case of a group with a Dutch parent company owning shares in subsidiaries incorporated in the Netherlands and in subsidiaries incorporated in other jurisdictions, Dutch corporate law applies to the parent company and to the Dutch subsidiaries. Each of the non-Dutch group members continues to be governed by the corporate law of the jurisdiction where they were incorporated. Nonetheless, in the case that such a non-Dutch company does

56. The synthesis is based on the information revealed in the Mapping Papers and the law of Albania. See further Kraakman et al. 2009.

57. Mähönen \& Villiers 2015.

58. Exceptions can be found in Danish law, see Danish Mapping Paper, §6, p. 37; §1.2.3.4, p. 9: “Whereas the Danish Companies Act only to a limited extent applies to parent companies situated outside Denmark, it more often applies to subsidiaries outside Denmark."

business in the Netherlands, then other types of Dutch law may apply to activities which such company employs in the Netherlands (e.g. labour laws, environmental laws and tax laws). That means that if a group consists of multiple group companies that are registered in various jurisdictions, the company acts of each of those jurisdictions apply to the company or companies incorporated in that jurisdiction. Consequently, in that case, and this occurs often, a number of company acts applies simultaneously to the group, which may complicate the matter of finding a comprehensible corporate law approach on group governance (see the barriers presented in section 5.1.3).

\subsubsection{Separate Legal Personality and Limited Liability of Group Companies}

In all jurisdictions surveyed, the basic principles of corporate law which apply to a single company appear to apply in the same or a similar way when this company becomes part of a group. The separate legal personality of each group company is the starting point of any discussion. The distinction between a group company's and its shareholder's assets and liabilities is thus overall an unquestioned principle. ${ }^{59}$ The parent company, each subsidiary and other group company can benefit from limited liability even when it is part of a corporate group. As an exception, some jurisdictions impose liability on the parent company in connection with the affairs of the subsidiary in certain circumstances. E.g., Albanian and Australian corporate law confer to parent companies certain responsibility for losses of subsidiary companies. Under particular circumstances, Spanish and Finnish environmental laws impose liability on parent companies for environmental damage caused by subsidiary companies. ${ }^{60}$

In groups, each of the group companies has its own articles of association. An interesting deviation was found in Chinese corporate law, which allows a parent company to formulate 'group articles of association' as the common criteria of behaviour (see section 4.3).

\subsubsection{Full Legal Capacity of Group Companies}

In most jurisdictions, the group members are not restricted in the execution of their power; however, certain actions such as voting on shares in group companies have been restricted by Japanese law; cross-holdings by subsidiaries in the share capital of the parent company are restricted in Japan and India, although exceptions apply. Parent companies are generally regarded as shareholders with no special rights in regard to group companies in terms of imposing decisions, programmes and asking information about group companies' activities. In some jurisdictions (Germany, Turkey, China, Slovenia, Hungary), corporate law explicitly allows that the parent company imposes group policies on the group companies or gives instructions to the group

59. UK Mapping Paper, §6.1, pp. 55-56; South African Mapping Paper, §C. 6 at pp. 50-51.

60. See the Spanish and Finnish Mapping Papers and the analysis hereof in the context of liability in Anker-Sørensen 2014. 
companies' management (this will be explained in detail in sections 4.2 and 4.3). In other jurisdictions, parent companies can make use of their rights as a shareholder to impose control. Shareholders usually can ask information from the company in which they hold shares; however, the subsidiary is generally not obliged to answer the question albeit that open norms of reasonableness and fairness can lead to an obligation to answer the question. ${ }^{61}$ An interesting statutory approach was found in Japan, where a parent company is entitled to require information from the subsidiaries just because it is the head of the group.

\subsubsection{No Explicit Obligation for Corporate Groups to Adopt a Climate Change Mitigation Programme}

In none of the jurisdictions examined, does substantive corporate law regulate that a parent company of a group defines a climate change mitigation strategy for the group and implements this. Only in the field of corporate annual reporting does the EU Directive on nonfinancial information state that climate change is a topic to report on. This applies to (consolidated) annual management reports pertaining to book years starting in 2017 (see section 3). The text of this Directive does however not establish any explicit connection with EU environmental law. We note that in all jurisdictions, environmental laws are the bodies of laws that regulate environmental issues, among which climate change. Usually, there are no linkages between environmental law provisions on the one hand and corporate law provisions on the other hand. Only in Spain, environmental liability law refers to the definition of a group as provided for in the commercial laws for accounting purposes.

\subsection{Identifying a Corporate Group - Parent and Subsidiary Relationships and the Concept of Control}

This issue of control and (potential) power, whether as a shareholder or pursuant to a contract, or actual, is central to all corporate law definitions of groups, parent and subsidiary companies. Some jurisdictions provide for a straightforward system to explain what constitutes a group of companies, which rights, duties and liabilities apply to the head of the group, and what kind of control the parent company is allowed to exercise. Others provide a less elaborate approach, but not surprisingly, through all jurisdictions we notice a large amount of similarities. ${ }^{62}$ Parent and subsidiary companies are sometimes referred to as 'controlling companies' and

61. See e.g. Article 2:8 Dutch Civil Code. In Norway, a fully owned subsidiary is obliged to answer a request for information by the parent company (information provided by Linn Anker-Sørensen on 5 February 2015).

62. See Mähönen \& Villiers 2015. Accounting law is relevant when looking for a definition of corporate groups, as well as accounting standards that are promulgated by professional accounting organizations, including International Financial Reporting Standards (IFRS) and US Generally Accepted Accounting Principles (US GAAP), and the locally applicable national standards and principles (local GAAP), such as those created by the Accounting Standards Board in the UK. Listed companies are often subject to additional reporting requirements imposed by securities law regulation and securities exchanges. 'controlled companies'. Group companies are also referred to as 'linked companies', 'affiliated companies', 'related companies' and 'financial participations'. In Europe, the EU Accounting Directives have largely harmonized these concepts amongst the $28 \mathrm{EU}$ Member States. They provided precise instructions to EU Member States as to how to prescribe in their national corporate or accounting laws which companies are to be considered a group that needs to publish consolidated accounts. ${ }^{63}$ Furthermore, the International Accounting Standards (IAS) have also had a converging influence among the various jurisdictions as regards the terms corporate group, subsidiary, affiliated and parent company. ${ }^{64}$

Among the examined jurisdictions, the most detailed definitions of what is considered to be a group, a subsidiary or a parent company, and how 'control' is determined, come from those jurisdictions in which corporate law expressly regulates groups. This is the case in

63. Until 2013, the important Directives were the Fourth and Seventh Council Directives, supra note 38. In 2013, they were repealed by Council Directive (EC) 2013/34, supra note 38, which Directive has to be implemented in national legislation by 2015 . Article 22(6) states: "Without prejudice to Articles 23(9), a parent undertaking and all of its subsidiary undertakings shall be undertakings to be consolidated regardless of where the registered offices of such subsidiary undertakings are situated". Article 22 states: "A Member State shall require any undertaking governed by its national law to draw up consolidated financial statements and a consolidated management report if that undertaking (a parent undertaking): (a) has a majority of the shareholders' or members' voting rights in another undertaking (a subsidiary undertaking); (b) has the right to appoint or remove a majority of the members of the administrative, management or supervisory body of another undertaking (a subsidiary undertaking) and is at the same time a shareholder in or member of that undertaking; (c) has the right to exercise a dominant influence over an undertaking (a subsidiary undertaking) of which it is a shareholder or member, pursuant to a contract entered into with that undertaking or to a provision in its memorandum or articles of association, where the law governing that subsidiary undertaking permits its being subject to such contracts or provisions. A Member State need not prescribe that a parent undertaking must be a shareholder in or member of its subsidiary undertaking. Those Member States the laws of which do not provide for such contracts or clauses shall not be required to apply this provision or (d) is a shareholder in or member of an undertaking, and: (i) a majority of the members of the administrative, management or supervisory bodies of that undertaking (a subsidiary undertaking) who have held office during the financial year, during the preceding financial year and up to the time when the consolidated financial statements are drawn up, have been appointed solely as a result of the exercise of its voting rights; or (ii) controls alone, pursuant to an agreement with other shareholders in or members of that undertaking (a subsidiary undertaking), a majority of shareholders' or members' voting rights in that undertaking. The Member States may introduce more detailed provisions concerning the form and contents of such agreements. Member States shall prescribe at least the arrangements referred to in point (ii). They may subject the application of point (i) to the requirement that the voting rights represent at least $20 \%$ of the total."

64. See Mähönen \& Villiers 2015. 
Germany, ${ }^{65}$ Slovenia, ${ }^{66}$ Albania,${ }^{67}$ Hungary ${ }^{68}$ Macedonia, ${ }^{69}$ Brazil $^{70}$ and Turkey. ${ }^{71}$

A legal distinction drawn in several jurisdictions is that between formal groups and factual groups (also referred

65. A 'group' covers legally independent enterprises which can be linked to each other in various ways: $\S 16$ AktG (majority-held and majorityholding enterprises); § 17 AktG (controlled and controlling enterprises); $\S 18$ AktG (group enterprises); § 19 AktG (enterprises with cross-shareholdings); or §§ 291, 292 AktG (parties to an intercompany agreement, also referred to as controlling agreement), cf. German Mapping Paper, §F at pp. 33-34.

66. Slovenian corporate law also recognizes multiple ways of how a 'group' can be formed: if one company has an equity participation in the capital of another company; if there is a contract between companies aimed at group forming (like in Germany); or based on actual circumstances. The key feature of a group is "that it consists of a dependent company and a dominant company which has a decisive influence on the administration and management of the dependent company", cf. Slovenian Mapping Paper, §5.3.A at p. 34. A dominant company can control the dependent company in different ways. The control can be based on legal criteria such as that the dominant company has a majority shareholding in the dependent company, or on a 'controlling contract'. However, in all situations there are some common features: "(i) the dependent company cannot formulate its will freely; (ii) the dominant and the dependent company are restricted in taking decisions concerning the protection of the assets of the dependent company; (iii) there is a basis for controlling the dependent company", cf. Slovenian Mapping Paper, §5.3.A at p. 34, fn 235; Ivanjko, Kocbek \& Preliç 2009, p. 970.

67. Article 207 of the Albanian Law No. 9901, date 14 April 2008 On Entrepreneurs and Companies, distinguishes between a 'control group', i.e. a group in which "one company regularly behaves and acts subject to the directions or instructions of another company", and an "equity group', i.e. a group based on legal criteria. These legal criteria are: a parent company has the right to appoint at least $30 \%$ of the members of the Board of Administration or Supervisory Board or of the administrators of another company; or it has at least $30 \%$ of the votes at the General Meeting, (The same applies where those rights are exercised through another company, controlled by the parent or a third party acting on account of that other company or the parent itself). These rights may originate from owning share capital share in that other company or from an agreement with that other company. Article 208 of the Albanian Law No. 9901 imposes notable duties and liabilities on parent companies towards subsidiary companies (covering losses) and towards creditors of the subsidiary companies (offering security for claims owed by subsidiaries).

68. Hungarian Mapping Paper, § 1.2 .3 at p. 6, §C.6.1, pp. 19-20; sections 55 \& 64 Hungarian Act IV 2006 on Business Associations.

69. Macedonian Mapping Paper,§1.2.3 at pp. 7-8. Article 491 of the Macedonian Company Law provides a definition for related companies, i.e. controlled and controlling companies.

70. Brazilian Mapping Paper, § A.3 at p. 4; Articles 1097-1101 Brazilian Civil Code.

71. Turkish Mapping Paper, §C.1 at p. 49. The 2011 Turkish Company Code determines that a 'controlling company' is considered to be a parent company while the 'controlled company' is considered to be a subsidiary. Articles 195(1) and 195(2) provide the criteria for what constitutes 'control', i.e. when one company holds the majority of the voting rights in another, or can take a resolution in the management body of another company, hence a legal criterion. 'Supposed control' applies when one company holds the majority of the shares of another company, but if the parties can prove that no actual control is being exercised, they are not subjected to the group law. to as de facto groups). ${ }^{72}$ First, a formal corporate group, equity group or contract group is commonly settled on the basis of legal arguments, e.g. the percentage of voting rights, share ownership and board influence are important tools used to determine whether one company has control over another company. Second, a factual corporate group is constructed by the existence of actual control. Domestic regulations of de facto groups are more diverse.

Other elements are taken into account to identify how control takes place in actual groups. In general, we observed certain key descriptions regarding control in a group: "the management of the controlling company may give orders to the management of the controlled company" company and a dominant company which has a decisive influence on the administration and management of the dependent company"74 (Slovenia); "where one company is accustomed to act in accordance with the directions or instructions of another company" 75 (Albania).

Some jurisdictions acknowledge both categories of groups (formal and factual groups). ${ }^{76}$ An example of a jurisdiction where the relevant criteria for both categories of corporate groups are clearly developed is Brazil.

72. See e.g. Hungary (see Hungarian Mapping Paper, \$1.2.3 at p. 6, §C.6.1, pp. 19-20; sections 55 \& 64 Hungarian Act IV 2006 on Business Associations); Slovenia (see Slovenian Mapping Paper, §5.3 at pp. 34-35; Articles 528 \& 533 Slovenian Companies Act), Germany (see German Mapping Paper, §F at p. 34; §§ 291-292 \& 311 German Stock Companies Act), Albania (even though there is a distinction between a control group and an equity group, basically it resembles the de facto group and a formal group as recognized in other jurisdictions, cf. Article 207(1)-(2) of Albanian Law No. 9901, date 14 April 2008 On Entrepreneurs and Companies); Turkey (control group and supposed control group, see Turkish Mapping Paper, §C.1 at p. 49; Article 195(1)-(2) Turkish Commercial Code), China (Chinese Companies Act Article 15(iii) cf. (Article 217(2). A 'controlling shareholder' [under Chinese corporate law] refers to: a shareholder whose capital contribution occupies 50\% or more in the total capital of a LLC; a shareholder whose stocks occupies more than $50 \%$ of the total equity stocks of a joint stock limited company; or a shareholder whose capital contribution or proportion of stock is less than $50 \%$ but who enjoys a voting right according to its capital contribution or the stocks it holds is large enough to impose an big impact upon the resolution of the shareholders' meeting or the shareholders' assembly.) The Company Law also acknowledges the phenomenon of an 'actual controller', e.g. though agreement, de facto directors or shadow directors (Article 217 Company Law). The term 'actual controller' refers to anyone who is not a shareholder but is able to hold actual control of the acts of the company by means of investment relations, agreements or any other arrangements. As controlling shareholder or actual controller, a parent company shall not injure the interests of a subsidiary company by taking advantage of its connection relationship (Article 21 Company Law)).

73. Hungarian Mapping Paper, $\$ 1.2 .3$ at pp. 6-7. See also: section 64 in conjunction with section 60 Hungarian Companies Act 2006.

74. Slovenian Mapping Paper, $\$ 5.3$ at p. 34.

75. English translation of Article 207(1) of Albanian Law No. 9901, date 14 April 2008 On Entrepreneurs and Companies.

76. See e.g. Hungary (see Hungarian Mapping Paper, $\$ 1.2 .3$ at p. 6, $\S C .6 .1$, pp. 19-20; sections 55 \& 64 Hungarian Act IV 2006 on Business Associations); Slovenia (see Slovenian Mapping Paper, \$5.3 at pp. 34-35; Articles 528 \& 533 Slovenian Companies Act), Germany (see German Mapping Paper, §F at p. 34; §§ 291-292 \& 311 German Stock Companies Act); Albania (Article 207(1)-(2) of Albanian Law No. 9901, date 14 April 2008 On Entrepreneurs and Companies); Turkey (see Turkish Mapping Paper, §C.1 at p. 49; Article 195(1)-(2) Turkish Commercial Code). 
The existence of a 'controlled company'77 can either be based on a 'majority control', ${ }^{78}$ i.e. relying on legal criteria and resulting in a formal group, or the controlled company can be subject to 'effective control', which then produces de facto group. 'Effective control' can be exerted by natural or legal entities that do not have the majority of voting rights but which have control in one of the ways outlined in Instruction 247/96 of the Comissão de Valores Mobiliários: ${ }^{79}$

a. shareholders agreements;

b. supply of technical assistance or essential technical information related to the activities of the beneficiary of the investment by the investor to the beneficiary;

c. significant technological or economic and financial dependence between the beneficiary and the investor;

d. permanent receipt, by the investor, of detailed financial information, as well as investment plans of the beneficiary of the investment;

e. common use of material, technological and human resources; or

f. control of access of inputs and commercial restrictions.

We observe that the fact that these criteria are set forth in a regulation can be considered an innovative corporate law approach. In most jurisdictions, the criteria to determine whether there is a formal group can be found in the law, but concepts as a factual group and effective control are often not clearly defined in corporate law.

Distinct from jurisdictions acknowledging both formal and factual corporate groups, there are jurisdictions where corporate law only refers to one of them. For example in Denmark, only the criteria of a factual group are relevant in determining the existence of a group ${ }^{80}$ This seems to be in contrast to the other Nordic countries, which apply a formal approach of group recognition. ${ }^{81}$ The same is the case in the Netherlands where a formal (ex ante) criterion to identify a subsidiary company is applicable: the key factor is the potential power to control through the exercise of voting rights (in the General Meeting or regarding the appointment and discharging of Board members). ${ }^{82}$ The Dutch definition of

77. Articles 1097 to 1101 Brazilian Civil Code, cf. Brazilian Mapping Paper, $\S A .3$ at p. 4.

78. 'Major control' is performed by natural or legal entities that have, directly or indirectly, more than $50 \%$ of voting rights and that possess, in a permanent way, the majority of votes in the company deliberations and the power to elect the majority of managers.

79. Most of the criteria are provided by Instruction 247/96 of the "Comissão de Valores Mobiliários - CVM"

80. Section 7 of the Danish Companies Act implements the Second Council Directive (EEC) $77 / 91$ (77/91/EEC) on coordination of safeguards which, for the protection of the interests of members and others, are required by Member States of companies within the meaning of the second paragraph of Article 58 of the Treaty, in respect of the formation of public limited liability companies and the maintenance and alteration of their capital, with a view to making such safeguards equivalent [1977], OJ L 26/1, and Council Directive (EC) 2004/109 on the harmonization of transparency requirements in relation to information about issuers whose securities are admitted to trading on a regulated market and amending Directive 2001/34/EC, OJ L 390/38. This section defines what control is, and when it exists, see Danish Mapping Paper, §1.2.4.2 at pp. 7-8 a group company, however, relies on the economic situation in which the legal entities operate: a 'group company' is a legal entity that belongs to an 'economic unit' in which legal persons and commercial partnerships are organizationally interconnected (Article 2:24b of the Dutch Company Act), i.e. an ex-post criterion representing effective control. ${ }^{83}$ Other jurisdictions that sole-
81. See e.g. Norway, a legal criterion is utilised: a 'parent company' is a company which has the majority of voting shares or otherwise elects the majority of the board members of the subsidiary (Norwegian Mapping Paper, $\$ 1.2$ at p. 3; §1-3 Norwegian Companies Act); a group can also be established through an agreement, §1-3(2) Norwegian Companies Act. This serves as an additional option to the two main formal criteria of majority (votes, or board composition). In Sweden, the legal criterion is that a parent company (i) has more than half of the votes for all shares or parts in the other legal person; (ii) owns shares or parts in the other legal person and because of an agreement with other owners in this legal person controls more than half of the votes for all shares or parts in that second legal person; (iii) owns shares or parts in the other legal person and has the right to appoint or remove more than half of the members of the board of directors or similar organ in that other legal person; or (iv) owns shares or parts in the other legal person and has the right to independently exercise a decisive influence over that legal person because of agreement with that legal person or because of its articles of association, a shareholder's agreement or similar statutes (see Swedish Mapping Paper, §1.2 at p. 5; section 11 Swedish Companies Act). According to § 8:12(1) and (2) of the Finnish Companies Act, if a limited liability company exercises control over another domestic or foreign corporation or foundation, the limited liability company shall be the 'parent company' and the other corporation or foundation a 'subsidiary' (see Finnish Mapping Paper, §7.1, p. 40).

82. Article 2:24a-1 of the Dutch Civil Code defines the 'subsidiary' as a legal person in which the parent company, or one of its subsidiaries, pursuant to a proxy agreement or without, is able to exercise, solely or jointly, more than one half of the voting rights at the General Meeting. or to appoint or discharge, solely or jointly, more than one half of the members of the Board of Directors or the Supervisory Board, even if all persons entitled to vote would cast their vote. There is no definition for what constitutes a parent company, but it can be deducted that it is the legal person which has a controlling interest within the meaning of Article 2:24a and is thus able to exercise a decisive control over another legal person. See Dutch Mapping Paper, §1.2 at pp. 8-9.

83. Due to the differentiated terminology, we must conclude that not every group company is also a subsidiary company under Dutch law, nor that every subsidiary company automatically is a group company. It is generally assumed that the definition of subsidiary also applies to foreign legal entities, which is interesting since generally, company acts only apply to the companies incorporated in their jurisdiction, cf. Asser/ Maeijer, Van Solinge \& Nieuwe Weme 2-II* 2009, nr. 820; Bartman \& Dorresteijn 2013, p. 39. In fact, it means that a Dutch company can become a parent company if it has a foreign subsidiary. 
ly apply the formal criteria for group recognition are e.g. Ireland, ${ }^{84}$ India, ${ }^{85}$ Australia ${ }^{86}$ and Japan. ${ }^{87}$

Concluding, there are many ways in which a group is defined according to the corporate laws of the examined jurisdictions. As regards formal groups, which mostly utilize legal criteria - often the criteria that are also relevant for determining which companies and entities are included in the consolidated accounts - the boundaries of a group are reasonably identifiable. In regard to de facto groups, the group boundaries are however less clear. An interesting regulatory example is the way in which Brazilian corporate law offers criteria to establish the boundaries of a factual group.

\subsection{A Common Group Strategy - Facilitation by Corporate Law}

As regards the presumption that corporate groups have a common group strategy that has to be complied with by all group members, we will find out that this is not always obvious. Parental exercise of control over group companies may trigger a conflict between the interest of

84. Irish Mapping Paper, §1.2 at pp. 13-14: section 155 of the Irish Companies Act, 1963 applies a legal criterion to identify a 'subsidiary company'. Section 155 of the Irish Companies Act 1963 provides: "a company shall be deemed to be 'a subsidiary' of another company only if the latter: (i) is a member of it and controls the composition of its board of directors; (ii) holds more than half in nominal value of its equity share capital; (iii) holds more than half in nominal value of its shares carrying voting rights (other than voting rights which arise only in specified circumstances)"; or the first company is a subsidiary of any company which is the latter's subsidiary. A 'parent company' or 'parent undertaking' is defined as "a company that has one or more subsidiary undertakings" within the meaning of the European Communities (Companies: Group Accounts) Regulations 1992 (SI No. 201 of 1992).

85. Indian Mapping Paper §VI at pp. 22-23. In India, Section 4 of the Companies Act 1956 defines 'holding company' and 'subsidiary' on the basis of legal criteria. The definitions are very similar to the ones found in the European corporate laws. A company will be regarded as subsidiary of another company if the latter controls the composition of its board of directors or holds more than half in nominal value of its equity share capital. (Or if it is a subsidiary of a third company which itself is a subsidiary of the controlling company.) The holding company shall be deemed to control the composition of the board of a company if it "has the power, without the consent or concurrence of the other person, to appoint or remove the holders of all or majority" of the directors.

86. Australian Mapping Paper, §VI.A at pp. 34-35. Section 50 of the Australian Corporations Act 2001 states the circumstances under which companies are considered related to each other. Like in the Netherlands, a parent company is seen through the lens of a subsidiary and thus only the term 'subsidiary' is defined (section 46). The power of a parent company to control the subsidiary's board's composition must be 'a legally enforceable power' and not just a de facto control. For testing whether a subsidiary relationship exists, the same legal criteria are applied as in most of the jurisdictions discussed in section 3.3.1. Furthermore, according to the Australian Accounting Standards Board (AASB), a parent company (with some exceptions) is required to prepare consolidated financial statements for the whole group.

87. Japanese Mapping Paper, $\$ 1.3$ at pp. 5-6. The Japanese Mapping Paper informs that under the Japanese Companies Act 2005, "the company is required to submit the securities report under FIEA, where the submission of consolidated accounts is compulsory. For reporting purposes, FIEA and listing rules of the stock exchanges add particular requirements to disclose the figures of a corporate group comprising listed companies and 'related parties' transactions as well". Clearly, the Japanese Companies Act 2005 uses a legal criterion; it provides that 'subsidiaries' are share companies (or other legal entities recognized by the regulations), of which the majority of voting rights are held by other companies. 'Parent companies' are companies which hold shares in subsidiary companies (or other legal entities recognized by the regulations. the parent company and the interest of the subsidiary companies. The legal question would be whether the subsidiary is obliged to follow a group policy determined by the parent company.

The concept of 'group interest' can provide a parent company's board with an important instrument to manage the whole group and to impose a common strategy. Some jurisdictions apply the concept of 'group interest' as an accepted tool to manage the group of companies in the benefit of the group as a whole. ${ }^{88} \mathrm{We}$ have not found any jurisdiction where the concept is further elaborated as regarding the proper content of group interest, and hence the concept is broad and open. A group strategy or policy is supposed to include the interests of the group companies and also to be equally binding upon all group companies. This is apparent in e.g. Germany, where the duties of a director of an affiliated company will change pursuant to a control agreement (or intercompany agreement): the director will no longer manage the group company in its own interest but has to do this in the interest of the group. ${ }^{89}$ Whether the applicable German group interest is a standard viable for other jurisdictions is questionable, as no clear criteria are provided.

According to Turkish corporate law, directors of a fully owned subsidiary have to obey the order of the parent company, to the extent that the latter is acting according to a 'predetermined group policy'. ${ }^{90}$ This 'group policy' is a document that we did not come across in other jurisdictions. We note that unfortunately the Turkish new Company Law does not precisely instruct how the group policy has to be determined, i.e. who has influence on the content, what subjects need to be covered and whether it should be formulated in general wording or in detail, nor does the law provide in which way the group policy has to be communicated in the group. However, introducing the concept of a group policy in corporate law on groups seems to us as a fruitful regulatory approach; a group policy will be an adequate instrument for any multinational enterprise; it can assist in delineating the roles of the various group members and in outlining the common objectives (see further section 5.2 in which regulatory options are presented in view of responding to the main research question).

88. See e.g. Article 209(1)(2) of the Albanian Law No. 9901, date 14 April 2008 On Entrepreneurs and Companies; The South African Mapping Paper, §C. 6 at p. 51, indicates that even though groups are often managed as economic units rather than separate entities, directors still only have fiduciary duties towards their own company. See also the discussion in the European Commission about group interest in $\operatorname{COM}(2012)$ 740/2 Communication from the Commission to the European Parliament, the Council, the European Economic and Social Committee and the Committee of the Regions Action Plan: European company law and corporate governance - a modern legal framework for more engaged shareholders and sustainable companies, pp. 13-14.

89. See the interesting example regarding German AG, Vertragskonzern (and in particular the 'Beherrschungsvertrag') in the German Mapping Paper, §F.I.1.A at pp. 35-36. See also; §308(1)-(2) German Stock Corporation Act 1965.

90. Art. 203 Turkish Commercial Code, see also: Turkish Mapping Paper, $\S C .1$ at p. 51 
In regard to China, we note that the corporate law recognizes 'group articles of association', but this differs - depending on the particular content - from a group policy. ${ }^{91}$

By contrast, most of the European and Anglo-Saxon jurisdictions still adhere to the traditional principle that the parent and group companies have autonomous interests. For example, in Canada, Finland and Norway, the directors of a subsidiary or affiliated group have fiduciary duties to their company rather than to their parent company or any affiliated company. In addition, the law gives some protection to minority shareholders against oppression by any controlling shareholder(s). ${ }^{92}$ Corporate law in Macedonia, Albania, Turkey, the Netherlands and Germany provides in various ways protection to the board of a subsidiary company to withstand any 'incorrect' instructions from the parent company. ${ }^{93}$

Nevertheless, we noted that little by little in Denmark, the Netherlands ${ }^{94}$ and Sweden, case law and legislative amendments have commenced to use the term concurrence of interests. A similar approach can be assumed in Norway, where subsidiaries by practice apply a group (parent) interest. It has been argued that the Normegian Companies Acts should be changed to reflect practice, so that board members in subsidiaries are legally bound to promote the interest of the group. ${ }^{95}$ Currently, there is a

91. Chinese Mapping Paper, §C.6.1, at pp. 58-59. See Article 3 of the Chinese Measures for the Administration of Finance Companies of Enterprise Groups.

92. Canadian Mapping Paper, §II, at pp. 22-23; Section 241 Canadian Business Corporations Act.

93. Compare with the comments regarding Macedonian corporate law, where the subsidiary management body must prepare an annual report on the dealings with the parent company. See Macedonian Mapping Paper, §6.3 at p. 35; Article 501 Macedonian Company Law. The Finnish Mapping Paper indicates that the Finnish Companies Act does not offer this protection; $\$ 7.2$ at p. 41.

94. In the Netherlands, it is generally understood that the fiduciary duties of the parent company's management board in its capacity as a head of the group equally apply to all group companies. The traditionally considered principle that the parent and group companies have 'autonomous interests' (under Dutch law, a subsidiary company of a Dutch parent company is considered responsible for its own actions as any other independently operating legal person) has been slowly, through case law of the Dutch Supreme Court, and through legislative amendments, changed into the principle of 'concurrence of interests', see Bartman 2007. However, the more the parent company has dealings with the every-day dealings of the group companies and exerts more power and control, the bigger responsibility it takes; and ultimately, it also incurs the risk of being held liable, either for 'failed supervision' or according to the general rules of liability. The Dutch Mapping Paper informs that in fact, depending on the specific case, the chance that the parent company will be held liable is higher in the cases in which it exercised an intensive control over the policy and the implementation of the policy in the subsidiary company's affairs. See Dutch Mapping Paper, §7 at p. 36.

95. The Norwegian Mapping Paper continues: In that case, however, such an amendment proposal would also have to discuss whether the group should be seen as a legal entity, with responsibility for the parent company for the group as a whole - i.e. a break with the equal treatment of parent companies and other shareholders, and a big step towards a Norwegian "Konzernrecht". This is unlikely to happen, and underlines the importance of ensuring that boards of subsidiaries are made aware of the difficult situation they have come into. See Norwegian Mapping Paper, §6.3 at p. 43. legal risk for a subsidiary company in promoting the interests of the parent company to the detriment of its own interests.

Another interesting aspect is that in none of the jurisdictions we found rules that allow a subsidiary company to influence the group policy and the common objectives of the group. ${ }^{96}$ Nonetheless, this is an important legal question that emerges in case of acquisitions and takeovers, for example in the situation that the target company has a well-developed CSR policy and the acquirer does not value this theme and intends to change (minimize) the CSR ambitions.

Concluding, the German, Turkish and Chinese corporate law approaches, which stimulate a corporate group to develop a group strategy, are regulatory examples of ways in which corporate law can assist groups in formulating a common strategy.

\subsection{Rights and Duties of the Central \\ Management in Case of Parental Control}

Control as discussed in section 4.2 has two sides: on the one hand, legal or de facto control of one company over another may bring into being the qualification that the 'controlling company' is regarded as the 'parent company' or 'dominant company' and the other as the 'subsidiary company' or 'controlled company'. Hence, the qualification produces a legal situation in which group law provisions apply. On the other hand, control by a parent company is also stimulated by the law and corporate governance codes because it is expected of a head of a group that it (1) carefully manages the economic and other risks which the group members may incur and (2) organizes and manages the business of the whole group in an adequate and responsible way. ${ }^{97}$ Commonly, it is stipulated that it is the duty of the board of directors of a group to exert control over the group in order to organize the business well and reduce the risks, i.e. good leadership and management. In the Dutch Corporate Governance Code, risks in the context of CSR capable of causing damage to internal and external stakeholders are explicitly referred to. ${ }^{98}$

A distinction can be made between jurisdictions where parental control is regarded solely as a shareholder matter and jurisdictions where parental control triggers other corporate rights and liabilities. This corporate control mechanism in the latter group of jurisdictions is additional to the common ways in which a parent company can exert control as a shareholder, such as through

96. According to the Dutch Mapping Paper, in certain situations, the works council of the subsidiary can exert influence on an intended decision of a foreign parent company, cf. Court of Appeal Amsterdam 23 July 2013, JAR 2013/2, at 3.5-3.8.

97. See e.g.: Danish Mapping Paper, §6.1-6.2 at pp. 38-39; Article 115 Danish Companies Act; Swedish Mapping Paper, §2.2 at p. 11; Chapter 8, Section 4 Swedish Companies Act; Dutch Mapping Paper, §1.3, at p. 13; Article 2:128 Dutch Civil Code and Principle II.1 Dutch Corporate Governance Code.

98. Principle II.1 of the Dutch Corporate Governance Code prescribes that the Board of Directors define a CSR strategy, that the Board submits this for approval to the Supervisory Board and that the Board informs the General Meeting about it. See further Dutch Mapping Paper, §2.2, p. 13 and Lambooy 2010, pp. 119-120. 
voting in the shareholders meeting, and appointing and dismissing directors. Other ways of exerting control are by appointing the parent company itself as director at the subsidiary company's board, by appointing a nominee director or by the parent company acting as shadow director. In Ireland, the parent company has a right to "appoint nominee board directors. Such a nominee will keep its parent company informed in relation to the dayto-day operations of the subsidiary company". 99 Exerting control in this way is evidently also an option in other jurisdictions where a subsidiary is defined by a legal criterion by de facto and shadow directors. ${ }^{100}$ These options are quite commonly practiced in multinational enterprises and permitted in many jurisdictions. ${ }^{101}$ In Japan, the reform bill, which will enter into force in 2015, further strengthens the position of the parent as a shareholder by allowing shareholders who hold at least $1 \%$ of all voting rights or outstanding shares to bring a derivative action against the subsidiary's directors/officers. ${ }^{102}$

A parent company can also ask information. However, the question to what extent the subsidiary company must provide the requested information depends on the local corporate law under which the subsidiary is established. If the parent company is not the sole sharehold$\mathrm{er}$, the situation is more complicated, because in that case the subsidiary company must also observe the equality of shareholder information principle, which applies in many jurisdictions. A statutory extension of the parental right to information in its capacity as a shareholder is stipulated in Japan, where 'a Fapanese parent company is provided with rights to access a subsidiary company's information as part of fulfilling its monitoring functions'. This implies that for Japanese parent companies there are more means available for obtaining information than just asking this in the capacity as a shareholder. This strengthens the parent's control position. Similar corporate law provisions that support the con-

99. Irish Mapping Paper, §C.6.2 at p. 52. Under Irish corporate law, as part of its continuing relationship, transfers of property are common between parent and subsidiary companies and fall outside the disclosure requirements of section 29 of the Irish Companies Act 1990 in relation to acquisitions or disposals of non-cash assets. See also the Transparency Regulations 2007 (SI No. 277 of 2007) which serve to disclose the formation of groups based on inter-corporate stock ownership in publicly-traded companies (pursuant to the implementation of the Transparency Directive (Directive 2004/109/EC) into Irish Law). Intra-group transactions are excluded on the basis that directors of a parent company should be in a position to exercise sufficient control over the directors of their subsidiary companies. See Irish Mapping Paper, §C.6.2 at p. 52.

100. In the UK, a parent company can also be the 'shadow director' of its subsidiaries but directors must avoid conflicts of interest. See UK Mapping Paper, §C.6.1 at p. 55; cf. Swedish Mapping Paper, §C.6.3 at p. 18.

101. These options were explicitly mentioned in: Irish Mapping Paper, §C.6.2 at p. 52; UK Mapping Paper, §C.6.1 at p. 55.

102. As indicated in the Japanese Mapping Paper and the additional comments of the Japanese author in an email to the authors of this article dated 29 October 2014. trol position of the parent company can be found in Germany and Turkey. ${ }^{103}$

In Hungary, the most important legal consequence of parental control is the right of the parent to instruct the subsidiary. As mentioned above, according to Hungarian corporate law: "the management of the controlling company may give orders to the management of the controlled company". ${ }^{104}$ In Slovenia, the definition of a group relationship provides an insight in the level of parental control: "it consists of a dependent company and a dominant company which has a decisive influence on the administration and management of the dependent company". 105 These jurisdictions offer examples of the ways in which corporate law supports a parent company in implementing a central strategy (see further section 5.2 on regulatory options).

Furthermore, in respect of parental instructions rights, at first sight, the Swedish regulation seems comparable with the regulatory approach in the Netherlands, Ireland, Denmark, Norway and Finland, in which jurisdictions parental control lies primarily within the parents' capacity as a shareholder. Consequently, the roles of the organs in both the parent and the subsidiary company are the same as in any other non-group companies in terms of the duty of care, control and monitoring. The shareholders meeting in a subsidiary company has the same powers as a shareholder meeting in any other company. If and to the extent that a parent company gives instructions to a subsidiary company's board of directors or managing director, those instructions will be regarded as decisions by the subsidiary's shareholder meeting. However, an interesting aspect is that the Smedish Companies Act 2005 indicates that the parent company's board shall regularly assess the group's financial position. ${ }^{106}$ Pursuant to the duty of care and the duty of supervision, which a parent company's board of directors and the managing director have, they are supposed to exert control over subsidiary companies by influencing and monitoring them. Similarly in Norway, where "[ $\mathrm{t}]$ he board of directors of a subsidiary is obliged to furnish the board of directors of its parent company with the information that is necessary for the purposes of considering the position of the group and the results of the operation of the group". ${ }^{107}$ Likewise, "[a] parent company shall notify the board directors of a subsidiary of matters which may be of importance to the group as a whole. The parent company shall also inform the subsidiary's board of directors of resolutions that may be of importance to the subsidiary, before they are

103. Turkish Mapping Paper, §C.1 at pp. 48-54; Articles 195-210 Turkish Commercial Code; German Mapping Paper, §F.I.1.A at pp. 34-39; Articles 291-310 German Stock Corporations Act.

104. Hungarian Mapping Paper, $\$ 1.2 .3$ at p. 6.

105. Slovenian Mapping Paper, \$5.3.A at p. 34.

106. "The board of directors shall regularly assess the company's financial position and, where the company is the parent company in a group, the group's financial position". Swedish Mapping Paper, $\$ 2.2$ at p. 11; Chapter 8, Section 4 Swedish Companies Act.

107. Norwegian Companies Act $\S 6-16(1)$, see also: Norwegian Mapping Paper, §C.6.2 at p. 42. 
finally adopted". ${ }^{108}$ The Norwegian Companies Act thus provides a basis for mutual exchange of information making it possible for both the parent company and the subsidiaries to make informed decisions, as a matter of company law, primarily to promote the company's interest within the framework of legal compliance and ethical obligations. ${ }^{109}$ Mutual information provision between parent and subsidiary companies seems a practical and important tool for managing a group and at the same time assisting the subsidiary companies to fulfil their own corporate purpose (which under the current system of many company laws is still the prevalent rule). However, illegal instructions or instructions which are of such a general nature that they interfere with the fundamental responsibilities of the subsidiary's board and managing director must be disregarded by the latter. If the organs of the subsidiary company do not do so, the individual directors may be held personally liable for any damages caused internally to the subsidiary company or externally to creditors.

Various legal systems contain remedies regarding situations in which a parent company abuses its power and gives illegal or unfair instructions to its subsidiaries. For example, the Chinese Company Law states that "[p]roprietary shareholders, the actual controllers, directors, supervisors and senior managers of a company shall not take advantage of their affiliated relations to damage the interests of the company". ${ }^{110}$ Similarly in Slovenia, the parental control is formally restricted in the way that "the dominant and the dependent company are limited in making decisions on protection of the assets of the dependent company". ${ }^{111}$ In particular Macedonia, Turkey ${ }^{112}$ and Albania provide interesting solutions. ${ }^{113}$ In Macedonia an innovative approach to minimize the potential damages that can harm a subsidiary company can be found in the Company Law, which introduces a 'balancing principle', balancing the rights and responsibilities of the parent company. ${ }^{114}$ This translates into three aspects pertaining to the relationship between the related companies. The first aspect is

108. Norwegian Companies Act $\S 6-16(2)$, see also: Norwegian Mapping Paper, §C.6.2 at p. 42

109. We note that we have not seen this in other jurisdictions.

110. Article 21 Chinese Company Law. See also: Chinese Mapping Paper, §. 6.2 at p. 60

111. Slovenian Mapping Paper, §6.A at p. 38.

112. Article 204 Turkish Commercial Code (see also: Turkish Mapping Paper, $\S C .1$ at p. 52) prohibits a parent company from giving orders that are exceeding the assets of the subsidiary or endangering its capability to make payments. Consequently, the directors of the subsidiary are not liable for any decision they have taken in compliance with the Articles 203 and 204 Turkish Commercial Code. Like in Macedonia and Germany, in Turkey, the new Commercial Code imposes certain liabilities on the parent company if it performs its controls over the subsidiary unlawfully, in which case the parent company must compensate the loss of the subsidiary company, cf. Turkish Mapping Paper, §C.1 at pp. 51-52, see also: Article 202(1) Turkish Commercial Code.

113. E.g. Albanian company law stipulates that a parent company must cover any losses of the subsidiary company and offer security to the creditors of the subsidiary companies for claims owed by subsidiaries (Article 208 Albanian Law No. 9901, date 14 April 2008 On Entrepreneurs and Companies).

114. Macedonian Mapping Paper, §6.2 at p. 34. that it is anticipated that the controlling company exercises influence; this can be done in the form of an advice, suggestion or recommendation; it can come from the official managing body of the parent company but also from any third person representing it. The second aspect is that the parent company's influence might possibly damage the subsidiary company. The parent company's management must therefore apply diligence in exerting influence. The third aspect relates to the question whether a parent company needs to compensate the subsidiary company for any damage. If the parent company - for its own benefit - influenced a subsidiary company's decision, resulting in damage incurred by the latter, the parent company has to remedy the situation with a compensation that should be sufficient to make things as they were before the controversial decision. In order to be compensated for the damage, the subsidiary company must show that the parent company has indeed influenced the controversial decision. Albanian corporate law goes one step further and lays down that, regardless of the level of parental influence, a parent company should cover the losses of a subsidiary and be milling to offer security to third parties for claims omed by subsidiaries. ${ }^{115}$ Enacting these standards in corporate law can also contribute to exerting parental control in a fair way. This is the reason that Macedonian law obliges the management body of a subsidiary company to prepare an annual 'report on the parent-subsidiary relations', audited by a certified auditor, together with the audit of the annual accounts and the financial report. The report must disclose the relationship with the parent company, specify any harmful legal transactions or actions and inform whether the subsidiary company has suffered any damages not yet compensated. Failure to make the report can lead to liability of the management body of the subsidiary company for the damage, jointly with the parent company. ${ }^{116}$

Concluding, our research concerning which rights and duties have been conferred by law to a parent company with the objective to empower such parent company in controlling its subsidiaries revealed that few company acts contained provisions to that end. Whereas in all jurisdictions, parent companies can exert rights as shareholder of the subsidiary company, only the corporate laws of Japan, Sweden, Norway, Germany, Turkey, Hungary, Ireland, Macedonia and Albania provide examples of useful regulatory approaches. They offered additional instruments or rights to parent companies, such as the right to give instructions to or to obtain information from the subsidiary companies, that can assist parent companies in implementing a common strategy in the corporate group. Concerning the topic of collecting information, it is noted that as every parent company is subject to the corporate law of the jurisdiction in which it is incorporated or registered, incorporating information provisions in the jurisdiction of the

115. Article 208 Albanian Law No. 9901, date 14 April 2008 On Entrepreneurs and Companies.

116. Macedonian Mapping Paper, §6.3 at p. 35. 
parent company appears the most practical way of regulating this. This works best if in the jurisdictions under which the group companies resort, mirror provisions are adopted such as has been done in Turkey and Albania. ${ }^{117}$ After all, the subsidiary is primarily governed by the jurisdiction where it is incorporated. An information right of the parent without concurring obligations for foreign subsidiaries will resort no effect.

\section{Barriers and Opportunities in Corporate Law to Assist Groups to Effectively Address Climate Change}

In this section, the comparative synthesis presented in section 4 will be evaluated in the light of the main research question enquiring into the pressure that domestic corporate law systems put on corporate groups to meeting the expectations identified in section 3 , and the means offered by corporate law to corporate groups to facilitate this process and to fulfil the expectations.

Resuming, in section 3 it was discussed that international policymakers, both from the public and private sector, ${ }^{118}$ expect of MNEs that they contribute to combating global climate change. Complying with environmental law obligations, including the EU ETS, is a legal obligation of the companies that fall within the application of that system. However, only a limited group of EU based companies must comply with ETS. Moreover, these norms only apply to their EU based operations. Consequently, on a global scale, the ETS has a limited reach. Besides fulfilling such legal obligations, MNEs worldwide are expected to design and adopt climate change programmes which aim to substantially reduce GHG emissions caused by, directly or indirectly, their operations. They are encouraged to embark on a transition to a low carbon business model that relies on renewable energy sources. International policymakers (e.g. IPCC, UNCG, OECD and EU), civil society actors (e.g. WBCSD, IIRC, and GRI) and investors (e.g. CDP) have communicated these views. Interestingly, also a number of MNEs have expressed that they are taking steps into this direction. ${ }^{119}$

117. Turkish corporate law prescribes that the subsidiary's directors must obey the parent company's order to the extent that the latter is acting according to a pre-determined group policy. Cf. Turkish Mapping Paper, §C. 1 at p. 52; Article 203 Turkish Commercial Code; Article 209 in conjunction with Article 18 Albanian Law No. 9901, date 14 April 2008 On Entrepreneurs and Companies.

118. Regarding the private sector, see e.g. the 'CDP Climate Performance Leadership Index 2014', which reveals which companies around the world are doing the most to combat climate change; <www.cdp.net/en -US/Pages/disclosure-analytics.aspx>; and the WBCSD, which leads its members to engage in a transition to a low-carbon economy; WBCSD's Road to Paris and beyond; <file:///C:/Users/lambooy/Downloads/The $\% 20$ Road\%20to\%20Paris\%20and\%20Beyond-n.pdf>; websites accessed 27 January 2015.

119. Ibid.
In order to satisfy the expectations and to put the ambitions into practice, MNEs, which are mostly organized as corporate groups, must define a group strategy and adopt GHG emissions reduction targets, implement the strategy, monitor the efforts of the group companies to realize the targets, collect and analyse the results, share the results with investors and other stakeholders and subsequently improve the ways of implementing the strategy.

Underlying these expectations (i.e. the assessment framework of our analysis), lie the assumptions that MNEs deem it necessary, or are legally obliged, to adopt a climate change programme as part of their group strategy and that they have the means to implement this programme in the whole group. Moreover, it is presupposed that it is possible to determine what exactly comprises the group.

These expectations and assumptions relate directly to corporate law questions because this is the body of law that regulates the structure, the organization and the governance of corporate groups. As outlined in the methodology section (section 1.1), we identified three relevant questions in this respect: (1) what are the parameters corporate law provides to identify the group - where are the boundaries? (2) does corporate law oblige, or facilitate, that a group has a common strategy? and (3) does corporate law support the central management in enforcing the group strategy upon the group companies - i.e. an issue of control and governance and in collecting the required data from the group companies?

In sections 4.2-4.4, these corporate law questions have been analysed with respect to the 24 jurisdictions comprising the SCP. The findings exposed in section 4 will now be evaluated in order to find answers to the main research question, thereby identifying: (1) legal approaches which do not support the assumptions or which could be counterproductive in respect of realizing the expectations ('obstacles' or 'barriers') and (2) legal approaches which are or could be supportive in confirming the assumptions ('opportunities', 'options', or 'better law approaches'). In the first part of this section 5 , our discussions are presented concerning obstacles and barriers found in domestic corporate law in respect of mandating corporate groups in taking action on combating climate change and to assist them with the implementation thereof. In the second part of this section, we reflect on opportunities and better law approaches offered in domestic corporate law systems that can enable MNEs to effectively implement group climate change programmes.

\subsection{Barriers and Obstacles Found in Domestic Corporate Law in View of Realizing the International Expectations that MNEs Constructively Act on Climate Change}

5.1.1 Gap betmeen Economic Reality and Corporate Lam We observed that the fact that companies operate in a group does most often not seem a relevant factor in the 
context of corporate law. That is why we did not find many definitions on the 'corporate group' in the Mapping Papers. That is also why the legal notion that a company is a single legal entity does usually not change when such company becomes part of a group. Neither do the legal duties and rights of a board seem to alter when a company becomes a subsidiary company nor when this company becomes a parent company, i.e. heading a group of companies. Exceptions hereto, but only to a limited extent were found in the corporate laws of Albania, Australia, Germany, Hungary, Turkey, Japan and China.

These observations are peculiar, because in practice, if a company becomes part of a corporate group, the (power) situation changes significantly. The board of the parent company then most often decides what will happen in the group, also regarding the business operations of any group company and the risks and precautions it takes, including concerning climate change (i.e. within the boundaries of any applicable environmental and other pertinent laws). The management of a group company has to obey the parent company's board's instruction or takes a chance to be replaced by the parent's board. Hence, there is a gap between economic reality and corporate law. This makes the situation complex for MNEs.

It would be more consistent with economic reality if corporate law determines, for instance, that the leadership of a group is in the hands of the parent company's board, that this board is responsible for designing corporate strategy (which could include climate change strategies) and that this board will acquire new rights such as instruction and information rights in order to facilitate the implementation of the group strategy. We found interesting regulatory approaches in this respect in the corporate laws and/or governance codes of various of the assessed jurisdictions. They will be evaluated in section 5.2. One could also argue that economic reality requires that a parent company assumes various new obligations such as guaranteeing the implementation of group values and programmes and adequately addressing damages incurred by third parties and caused by group companies. The assessed corporate laws did not reveal any examples in support hereof except for Albanian corporate law, which contains provisions that tend to enterprise liability. ${ }^{120}$

\subsubsection{Historical Development of Company Lam}

Historically, corporate laws were designed to regulate the formal and administrative aspects of the establishment and the functioning of a company or other legal entity. Normative rules such as pertaining to how the company's board should take care of the company's employees or the environment were adopted as part of other bodies of law, e.g. labour law and environmental law. Many regulators and academics still argue that company acts should be curbed to the technical and for-

120. Article 208 Albanian Law No. 9901, date 14 April 2008 On Entrepreneurs and Companies, and see the artikel of Linn Anker-Sørensen in this issue. mal aspects of regulating companies. Nonetheless, times have changed. Looking at corporate groups in the international business arena and at the way in which these are managed, it is clear that a purely formal approach does not suffice anymore. International organizations such as the EU, the OECD and the UN address corporate groups as 'enterprises' (see above in section 3) ${ }^{121}$ and express an expectation that groups conduct their business in an honest and socially responsible way that contributes to the continuity of the group, comply with the laws in the countries where the group operates and adequately respond to social and environmental challenges, including climate change. These organizations even indicate that they anticipate that international enterprises influence their supply chain in such a way that the whole supply chain behaves sustainably. It has become clear that company law has not yet been adjusted to such expectations. It requires a shift of mind to modernize company law in the direction suggested by the EU, the OECD and the UN, that is to employ corporate law mechanisms to support environmental objectives.

\subsubsection{Company Lam Mostly Has a National Focus}

Arguments may be posed that corporate laws are purely national pieces of law. We note however, that for example in the EU, the Company Law Directives and the Accounting Directives have succeeded - be it up to a certain level - to harmonize corporate, financial market and accounting laws in the EU Member States. The EU Accounting Directives have also harmonized the group concept: they provide clear indications of what constitutes a group and how the group results should be consolidated and reported on in consolidated financial statements. Inspired by the German example, the EU has also attempted to harmonize and regulate group law as part of the Company Law Directives, ${ }^{122}$ but failed to succeed here. In spite of this, as it has been possible for the EU to prescribe group accounting laws for its 28 Member States, why would the EU not be able to create a new body of group law for its Member States which could be effective in reducing climate change? ${ }^{123}$ Beyond the scope of this article are the EU tax and competition laws, which also employ instruments to regulate international corporate groups. Indeed, it would be interesting to research the 'group' concept in these two bodies of law and to compare the findings thereof with

121. Compare for example with OECD 2011, supra note 20

122. Dorresteijn et al., 2009, pp. 281-306. See the Draft Proposal for a Ninth Council Directive (1985) pursuant to Article 54(3)(g) of the EEC Treaty relating to links between undertakings and in particular to groups, accessible at: <www.mhc.ie/uploads/9th_proposal.pdf>, accessed 19 November 2014

123. Such group law would strengthen the efforts of MNEs in respect of ETS, but would generate a larger effect as a MNE's climate change programme is supposed to cover the operations of all group companies, the EU ones as well as the non-EU ones. Moreover, such a programme requires group targets in respect of GHG emissions reductions that may well be more ambitious than the ETS, and the ETS only applies to a limited number of sectors. 
the findings on corporate law as reflected on in this article. $^{124}$

Although there are slight variations, in most of the jurisdictions examined, national corporate laws apply only to companies incorporated in that jurisdiction. We note that MNEs usually comprise companies which are registered in many different jurisdictions. Currently, for each of these group companies, the parent company has to examine local corporate laws to find out which rights, duties and liabilities apply to it as a shareholder and as a head of the group. This implies that different rules may apply to a parent company of a group, as we explained in this article; i.e. different rules about obtaining information, regarding the giving of instructions to group companies, etc. This situation makes it difficult for a parent company to collect the information needed to draft the consolidated accounts, because those accounts must include the financial results of all group companies, whether domestic or foreign.

However, this situation also leads to the conclusion that it would be technically possible to impose an obligation on a group's parent company to adopt common goals for the whole group, including on the matter of reducing climate change impacts and to implement this obligation in practice thereby using its rights as a shareholder. At least, it would be a possible approach in all jurisdictions to command that all companies, whose financial results are represented in the consolidated accounts, will also be the companies that must comply with the group's climate change policy and report on the results of implementing. In the same line, we can interpret the new EU Directive on non-financial information (see section 3 above).

\subsubsection{Group Interest versus Group Company Interest}

In most jurisdictions, the legal concept of autonomy applies to group companies. In legal theory, it is thus still a basic premise that the board of a group company is independent and formulates its decisions in the best interest of that company, its shareholders, creditors and employees. In some jurisdictions like the Netherlands, also the interests of the group company's other stakeholders must be taken into account by the board of the group company. We note that, nevertheless the group company's autonomy, the company may often benefit from special 'group facilities' offered by corporate law such as realizing a legal merger or demerger through a simpler procedure. Another facility is that a group company is often exempted from producing an annual report. These types of group facilities can be regarded as adding to the benefits of being a group member, thus contributing to the coming into existence of a group interest. Moreover, we noted in section 4 that in prac-

124. EU tax laws recognize groups in e.g. the Parent-Subsidiary Directive, the Royalty and Dividend Directive(s). In EU competition laws, including the EU Merger Control Regulation 139/2004 and the Articles 101 and 102 TFEU the group concept relates to joint economic power based on contractual and other relationships between the participants. See also the Dutch Competition Act, Articles 6, 24, and chapter 5, in which the economic power also plays a dominant rule. tice, a parent company has various means to exert control over its group companies; hence the independence of a group company and its managers is doubtful in practice.

However, this basic concept of autonomy of group companies can be considered an obstacle for introducing group obligations on climate change reduction in corporate law. The board of a group company may oppose against implementing GHG reduction measures because he or she reckons that these measures do not advance the situation of the group company.

Nonetheless, as we pointed out, interesting group law approaches were adopted in German law, Hungarian law, Slovenian law and Chinese law, which jurisdictions, respectively, acknowledge that a group has a group interest (Germany, Slovenia), a group policy (Hungary) or group articles (China). We also identified some jurisdictions where case law and/or legislative amendments are developing towards the point of view that group companies are considered to have concurrent interests. They thus have to pursue their own company interest but they must also try to align this with the common group interest (the Netherlands, Sweden, Denmark).

MNEs habitually have group mission documents and policies, although they are not always publicly accessible. Consequently, MNEs see themselves as groups with a group interest. Hence, we do not consider this traditional perception of autonomy of group companies a major obstacle for MNEs to introduce a group climate change programme. Nevertheless, it would be more clear if corporate laws would expressly acknowledge the situation that MNEs are working on the basis of group interest and would prescribe that a parent company formulate its group interest and disclose it.

\subsubsection{Rights and Duties within a Group Are Mostly Not Clearly Defined}

We noticed that some company acts contain rules concerning the due care which group companies should apply towards each other (mainly parent towards subsidiary company) and towards creditors (e.g. Macedonia). We analysed that in most jurisdictions, corporate law does not provide for a general or detailed description of the duties, rights and liabilities of group companies towards each other. Most of the rules, if any, concern the protection of the capital of the subsidiaries (i.e. that the parent company cannot drain the subsidiary company; see e.g. Albania, Macedonia). We did not come across any rules which relate to subject matters beyond the financial scope. Consequently, as yet, this constitutes an obstacle and need to be reformed in order to clarify the rights and duties towards each other in pursuing common goals.

\subsubsection{Opaqueness of Corporate Groups Based on Networks}

Besides forming corporate groups based on common equity interests, group structures also include relationships with other parties. Reference is made to network relationships aimed at establishing or maintaining a joint 
venture, a franchise, a distribution or a supply chain relationship as described in section 2 . These agreements create an organizational form under which one company might interfere with the daily operations of other companies. These types of contracts also provide to a controlling company the power to demand policy changes in the operating companies. However, responding to concerns such as climate change is usually not part of the network agreements. ${ }^{125}$ Currently, the opaqueness of these networks forms a barrier against effective regulatory approaches that aim at introducing climate change programmes in network group partners. The elusive nature of network groups, however, is not necessarily an insurmountable hurdle in regulation de facto groups explicitly. In the Brazilian Civil Code, both formal and de facto groups have been clearly and effectively defined. ${ }^{126}$

\subsubsection{Liability Shields between Group Companies Protect the Position of Parent}

We observed that in most jurisdictions individual group companies maintain their limited liability status when they become part of a group. There are a few jurisdictions in which corporate law under certain circumstances imposes liability on a parent company for losses of, or damages incurred by, subsidiary companies (Albania, Macedonia). And, in Spain and Finland, environmental laws take a similar approach in respect of environmental damages.

Accordingly, with the freedom provided by company laws, multinational groups can act in a creative way to organize their local and international operations. Creating subsidiaries in many different countries allows a parent company to work with a flexible structure and usually improves the international tax base of the group as a whole while insulating liability. Damage to the environment, including climate change, and to people in various places in the world, caused by group companies, remains legally speaking the problem of the local subsidiary companies. The liability shield works perfectly in this respect and protects the parent company against claims. We have not found any case law or examples where the parent company of an MNE stood up and voluntarily became a party in proceedings filed against a subsidiary company. Nor did we find information about parent companies that readily remedied any damages caused by their subsidiaries or network companies abroad. On the contrary, parent companies usually defend themselves by claiming that they had nothing to do with the damages and could not have prevented them. ${ }^{127}$ The comfortable position of MNEs in respect of liability questions does not encourage them to support any change in the present regulatory situation in corporate law as regards the limited liability status of group companies. MNEs are not eager to support any

125. Vytopil 2012.

126. Cf. Brazilian Mapping Paper, §A.3 at p. 4; Articles 1097-1101 Brazilian Civil Code.

127. See e.g. the formal defences by Shell and Chevron in Lambooy, Argyrou \& Varner 2013. amendment in the law concerning (group) liability (also referred to as 'enterprise liability'), nor do they usually respond enthusiastically to any proposals for introducing corporate law provisions that impose duties and responsibilities on parent companies in respect of responsibly managing the group and controlling its worldwide business activities to avoid negative impacts. ${ }^{128}$ In the US, EU, Australia and many other jurisdictions, MNEs have a strong say in law reform due to their active participation in consultation rounds and because of lobbying. We conclude that this represents a power-related barrier to really develop group law and probably also to mandate parent companies of MNEs to introduce effective climate change mitigation programmes.

\subsection{Options for Using Corporate Law on Groups to Empower MNEs to Constructively Act on Climate Change}

\subsubsection{Corporate Lam Approach on Climate Change Mitigation Goals and Programmes}

We observed that none of the company acts which were examined imposes a duty on a parent company's board to have a group climate change mitigation objective. Undeniably, that would be a desired step in order to effectuate a reduction of GHG emissions by MNEs. Between the lines, in the new EU Directive on nonfinancial information, discussed in section 3 , one can read that the Commission supports such an idea. The Directive stipulates that large companies and groups disclose 'information on policies, risks and results as regards environmental matters, social and employeerelated aspects, respect for human rights, anti-corruption and bribery issues and diversity on the boards of directors'. Climate change is a matter acknowledged by the Commission as an environmental challenge to which enterprises should prepare a response. ${ }^{129}$ It is stated in the background papers that one of the objectives of this Directive on non-financial information is that companies develop policies, estimate risks and measure results from implementing the policies, all directed at reducing GHG emissions by the group companies and will report hereon. However, the text of the Directive states that if a company or group does not have policies, it should explain this. Clearly, the Directive's text is a compromise.

Corporate governance codes were also examined in the Mapping Papers, but they also failed to precisely outline a process of the steps that should be taken by the parent company of an MNE to effectively control and influence the group in respect of mitigating climate change and other environmental impacts. Corporate governance codes focus on risk management but their approach

128. Compare the EU Commission Communication discussed in section 3 although the Commission did not propose new legislation in this respect, the Commission did state that CSR includes responsible management and avoiding negative impacts.

129. As is apparent because of introducing the ETS, and which was also explicitly communicated by the Commission in the definition of CSR in 2011. Supra note 29. 
basically focuses on damage control in relation to the MNE's earnings. In our view, effective control requires a broader perspective than a focus on financial returns and costs; it requires the availability of data concerning the environmental and social performance of the MNE in order to gain an insight in weaknesses and vulnerabilities of the business operations and above all an understanding is needed of the role the MNE plays and could play in the market and in society (opportunities). Consequently, it is certainly an option to include the theme of climate change programmes in national corporate governance codes, as it would enhance effective control of the group management. However, corporate governance codes are mostly drafted in aspirational and conceptual terms and their strength stops where the "comply or explain' begins. Consequently, in our opinion, they cannot take the place of a comprehensible corporate law approach, although they can certainly add to that.

A regulatory option would be to include in corporate law an obligation for parent companies heading large groups (1) to adopt quantifiable long-term and shortterm climate change mitigation goals and implementation programmes, (2) to determine a methodology to monitor the implementation and measure the results and (3) to record these in the consolidated annual report. When and where relevant, these goals should at least support the environmental law obligations of the group and the individual group companies in respect of any licences for emitting GHG and/or allowances under the ETS and other market-based regimes elsewhere in the world.

\subsubsection{Corporate Lam Approach on Group Interest and Group Policy}

A desirable situation for the implementation of a group climate change mitigation objective and programme would be if a group would have to formulate a group interest, common goals and a group policy. We noticed that German and Turkish corporate law stimulate a corporate group to develop a group strategy. We also refer to the Chinese corporate law, which stipulates that a corporate group can have one set of articles. We understand this as that groups should have a common charter. We also refer to the South African Mapping Paper, which informs that "when holding companies are united with subsidiaries to form groups, the management of the different entities is performed on the basis of what is in the benefit of the group as a whole".

If corporate laws would offer a standard to apply to define a proper group interest and set common goals, preferably with clear and common criteria, then it could be an effective mechanism to empower a parent company to pursue a common strategy. The criteria could include environmental sustainability, encompassing specific CSR criteria such as communicated by the EU Commission, the OECD and the UN. The parent company would then be assisted by corporate law when implementing its climate change mitigation programme, e.g. by setting group GHG emission reduction goals and dividing responsibility to achieve them over the group companies.

Such an approach would certainly bring corporate law closer to the situation in practice. In our view, such a more realistic regulatory approach would facilitate groups in successfully introducing climate change goals throughout the group.

\subsubsection{Corporate Law Approach on Information Exchange within the Group}

In order for an MNE to be able to effectively implement a climate change mitigation programme throughout the group, the central management needs to be allowed to exercise control over the group companies and network companies. The monitoring of the programme implementation requires a lot of information concerning the efforts and results of group companies. Information exchange is thus a crucial element of control. We observed that most jurisdictions allow the parent company in its capacity of shareholder to ask information from its subsidiary companies. However, the result of this request might be quite limited because the law does not see such information as necessary input for the central management but rather as information useful for the parent company as shareholder, i.e. investor information. Currently, it will be difficult in most jurisdictions for a parent company to legally force group companies to provide detailed information about commercial processes and results.

In the comparative synthesis, we encountered some innovative regulatory corporate law approaches on this topic:

- In Argentina, a company which holds more than 25\% of the capital of the other company must inform this to the latter so that its next regular assembly takes notice of the fact.

- Macedonian law stipulates that the management body of a subsidiary company prepares an annual 'report on the parent-subsidiary relations', audited by a certified auditor together with the financial statements.

- "a Japanese parent company is provided with rights to access a subsidiary company's information as part of fulfilling its monitoring functions".

- The Norwegian Companies Act determines that "a subsidiary's company's board must provide the parent company's board with any information that is necessary for an evaluation of the group's position and the result of the group's activities". Likewise, “a parent company must notify the boards of its subsidiaries of matters which may be of importance to the group as a whole. Specifically, the parent company must notify the subsidiary company's board of any decisions which may be important to the subsidiary company before a final decision is made". This Act thus provides a basis for mutual exchange of information, thereby allowing the parent company and the subsidiaries to make informed decisions.

We note that some of these corporate law approaches aim at creating transparency about group relationships 
and the influence of parental control; others endeavour to expand the access of information in connection with managing the business and taking decisions. Provisions that support information exchange between parent and subsidiary companies seem a practical and important tool for managing a group and at the same time assist the subsidiary companies to fulfil their own corporate purpose (which under the current system of many company laws is still the prevalent rule). If other jurisdictions would also adopt these kinds of approaches, they would generate useful instruments that can support the introduction of any new group policy and programme, e.g. on climate change mitigation.

\subsubsection{Options to Define a Corporate Group in the Context of a Climate Change Programme}

The question posed was how can a parent company determine which companies and other entities belong to the 'group' that has to implement a centrally designed climate change programme, implying that the parent company must be able to collect data from these group companies and entities on their GHG emissions reduction efforts and results.

There are many ways in which a group is defined according to the corporate laws of the examined jurisdictions. As regards formal groups, which mostly utilize legal criteria - often the criteria that are also relevant for determining which companies and entities are included in the consolidated accounts - the boundaries of a group are reasonably identifiable. In regard to de facto groups, the group boundaries are however less clear. The better law approaches also regulate factual groups (e.g. Brazil) and requires registration of groups (e.g. Brazil, Hungary and Turkey). Consequently, in order to identify a group, it would be useful to include in company acts, or in accompanying regulations, criteria for factual groups such as are legislated in Brazil. This will help to decide in respect of factual groups which companies and entities are to be included in the group's climate change programme.

Concerning identifying formal groups, one example of a corporate law approach is the new EU Directive on non-financial information. In section 3 , we pointed out that this Directive introduces the obligation for corporate groups registered in the $28 \mathrm{EU}$ Member States to include a non-financial information disclosure statement in their consolidated annual management reports (as of book years starting in 2017). Among other are such disclosures expected to include information on the group strategy on climate change, the risks involved and the results of their strategy. Although the text of this Directive is not very explicit, one can deduct that this information concerns all companies the results of which are included in the consolidated annual accounts. This EU approach appears coherent with other corporate law approaches and accounting law, and therefore appears a feasible option for determining which companies and entities should be covered by a group climate change programme.
Hence, we suggest that domestic corporate law could be used to introduce criteria for the identification of formal and factual groups. This would assist a parent company to decide to which entities the group climate programme applies. The better law approach links reporting on climate change programmes to annual financial reporting. Corporate law could for example prescribe that a parent company of a group reports, in its annual report, the application of the group climate change programme, thereby covering the data on GHG emissions of all group companies the financial results of which are included in the consolidated accounts. In respect of joint ventures and participations, percentages can be applied like this is the case regarding financial profits and returns. In this way, the group's GHG emissions (reduction) efforts can be related to the group's turnover and profits and can be compared by managers, investors and other stakeholders with the group's results of other years and with the data published by other corporate groups.

\section{Conclusion}

As argued in the introduction of this article, MNE's operations contribute to climate change and other environmental damages, hence there is an urgency to make them part of the solution. In order to delineate the subject matter of this article, in section 2, some background information was provided concerning the history and the variety in legal constellations of MNEs. In section 3, we noted that international regulators such as the EU and the UN, but also the OECD, have expressed the expectation that MNEs prevent adverse consequences resulting from their operations, including concerning climate change. To that end, MNEs are encouraged to implement climate change programmes throughout their group, to monitor the success of their programmes and to share these in annual reports. Consequently, one would assume that corporate law imposes an obligation on parent companies of MNEs to effectuate said expectations. Based on our comparative synthesis, we pinpointed that this is not the case, however. Currently, neither the EU Company Law Directives nor the domestic corporate laws of the 24 jurisdictions examined in this research project contain an unambiguous obligation directed at MNEs to do so. Nonetheless, we identified an interesting regulatory approach in the area of corporate reporting. In 2014, the EU adopted new legislation aimed at prescribing that large companies and corporate group publish non-financial disclosures, including information regarding the corporate (group) strategy on climate change. Although this Directive represents a development towards involving MNEs in climate change mitigation in a constructive way, it is noted that its instructions are not very detailed yet and that independent external verification of the data is not yet required. Nor does the Directive establish an explicit connection with the information EU companies have to 
provide pursuant to the ETS. We mentioned that the EU introduced the ETS as part of EU environmental law, but commented that this system has a limited application. That is, the cap and trade obligations are only imposed on large carbon emitting (industrial) establishments in the EU Member States, and on an individual basis. The ETS does not mandate an MNE to adopt a climate change programme that applies to all of its operations wherever located in the world, nor does it require of an MNE to monitor its global GHG emissions and report hereon.

Furthermore, we argued that the abovementioned expectations of the international organizations seem to presuppose that corporate groups, everywhere in the world, are well identified, that all group members follow a common strategy and that the parent companies can collect from group companies any data useful for implementing the group climate change programme and monitoring the same. Another presumption is that the MNEs measure such data in a reliable way that generates comparable information for regulators, investors and other companies.

In section 4, the analysis was presented as to what extent these presumptions correlate with the corporate laws covered by the Mapping Papers. Legal approaches that can support the presumptions were highlighted. Subsequently, in section 5, we evaluated the various regulatory approaches analysed in section 4 in the setting of the main research question that is in order to distil barriers and options of using corporate law for the promotion of corporate climate change programmes. As the best approach was not found in one jurisdiction, we combined a hybrid of many solutions with our own views.

We can draw some general conclusions. The first one is that the privileges offered by corporate law, i.e. the principle of separate legal personality, ${ }^{130}$ limited liability ${ }^{131}$ and full legal capacity, ${ }^{132}$ can hold back any responsibility, of an MNE, and hence enterprise liability, for any environmental harms, including contributing to climate change, caused by its group companies in various places in the world. The second general conclusion is that the analysis of the law on groups in this article has shown that this area of law is underdeveloped. Across the jurisdictions examined in the SCP, we found corporate law provisions that mandate corporate groups to publish consolidated accounts. However, other than that, not much has been arranged. Only very few jurisdictions provide clear instructions for groups or parent companies to define a group interest, set common goals and determine common policies, values, processes. Furthermore, almost none of the jurisdictions assessed provide for comprehensive regulatory approaches on information exchanges between group companies. This is regrettable, as such an approach could support a parent

130. Although corporate law generally allows de facto control over subsidiaries, this has been rarely regulated (see section 4).

131. That is, protecting shareholders from financial risks beyond their initial investment.

132. That is, e.g., a parent and group company' entitlement to own shares in other companies. company in exercising effective control over the group and its business and it could assist the subsidiary boards in acquiring more knowledge about the processes within the groups as well as the common goals and results.

With a view to the main research question whether corporate law on groups can support the introduction of climate change mitigation programmes by MNEs, we must conclude that most corporate laws today do not provide for many instruments to encourage that. We exposed several barriers in section 5.1, among which the lack of regulatory approaches on obliging groups to define common goals and to follow processes to achieve these common goals. We emphasized that corporate law has a narrow scope focussing on financial matters. We pointed at the opaqueness of corporate groups based on networks and networks integrated into corporate equity groups, and we questioned the practical applicability of corporate law in respect of international groups. However, in section 5.2, we also identified options for improving the use and instruments of corporate law in the fight against climate change. We proposed that corporate law include regulatory approaches on climate change mitigation goals and programmes, on group interest and group policy and on information exchange within groups. What also needs to be done in this context is to provide clear definitions that indicate the boundaries of economic groups of companies in respect of their duty to implement group climate change programmes. A practical approach, coherent with other corporate and accounting law approaches, would be to impose such a responsibility on the group's parent company and to state that it applies to all group companies whose financial results have to be included in the consolidated accounts.

The impact of MNEs for the climate change mitigation ambitions of the international community can be enormous. Hence, time is of the essence. ${ }^{133}$ MNEs can on a voluntary base adopt climate change programmes and some do. Nonetheless, in order to create a level playing field between MNEs across the world and to involve as many of them as possible, it would be an appropriate step to also include this as one of the subject matters where groups of company have to respond to in a structured way supported by law. Corporate law can oblige MNEs to formulate concrete goals, programmes and policies, methodologies to measure impact and results and to report on this. This is also the view of the EU Commission indicated in the CSR Communication 2011 and in the EU Directive on non-financial information. Corporate law can support environmental laws in the aim to reduce climate change, on the one hand, by mandating corporate groups to define goals and implement programmes and, on the other hand, by empowering them with tools necessary for adopting such programmes as part of the common group policy and for monitoring the implementation of the programmes by the group companies.

133. See also Mähönen \& Villiers 2015. 
The steps proposed in this article can form an appropriate base for the facilitation of corporate group-wide environmental policies, potentially to the benefit of the global challenge of mitigating climate change.

\section{Bibliography}

L. Anker-Sørensen, "Parental Liability for Externalities of Subsidiaries: Domestic and Extraterritorial Approaches", 3 The Dovenschmidt Quarterly 2014.

S.M. Bartman, "From Autonomy of Interests to Concurrence of Interests in Dutch Group Company Law", 4 European Company Lam 5, 2007, pp. 207-210.

S.M. Bartman \& A.F.M. Dorresteijn, Van het Concern, Deventer, Kluwer 2013.

R. Bauer \& D. Hann, Corporate Environmental Management and Credit Risk, 2010, available at <http://papers.ssrn.com/sol3/ papers.cfm?abstract_id $=1660470>$, accessed 18 November 2014.

Th.M. De Boer, "Vergelijkenderwijs: inspiratie van buitenlands recht”, 123 WPNR 1992, pp. 39-48.

C. Böhringer, "Two Decades of European Climate Policy: A Critical Appraisal", Reviem of Environmental Economics and Policy 2014, pp. 1-17.

R. Cafaggi, Contractual Networks, Inter-firm Cooperation and Economic Gromth, Cheltenham, Edward Elgar Publishing 2011.

R.E. Caves, Multinational Enterprise and Economic Analysis, Cambridge, Cambridge University Press 2007.

Centre for Strategy \& Evaluation Services (CSES), Disclosure of non-financial information by Companies, 2011, available at $<$ http://ec.europa.eu/internal_market/accounting/docs/non -financial-reporting/com_2013_207-study_en.pdf>, accessed 18 November 2014.

Council Directive (EEC) 77/91 (77/91/EEC) on coordination of safeguards which, for the protection of the interests of members and others, are required by Member States of companies within the meaning of the second paragraph of Article 58 of the Treaty, in respect of the formation of public limited liability companies and the maintenance and alteration of their capital, with a view to making such safeguards equivalent [1977], OJ L 26/1, accessible at <http://eur-lex.europa.eu/legalcontent/EN/TXT/PDF/?uri=CELEX:31977L0091\&from= en>, accessed 19 November 2014.

Council Directive (EEC) 78/660 on the annual accounts of certain types of companies [1978], OJ L 222/11, accessible at $<$ http://eur-lex.europa.eu/legal-content/EN/TXT/PDF/? uri=CELEX:31978L0660\&from=EN>, accessed 19 November 2014.

Council Directive (EEC) $83 / 349$ on consolidated accounts [1983], OJ L 193, accessible at <http://eur-lex.europa.eu/ LexUriServ/LexUriServ.do?uri=CELEX:31983L0349:en: HTML>, accessed 19 November 2014.

Council Directive (EC) 2003/51 amending Directives 78/660/ EEC, 83/349/EEC, 86/635/EEC and 91/674/EEC on the annual and consolidated accounts of certain types of companies, banks and other financial institutions and insurance undertakings [2003], OJ L 178/16, accessible at <http://eurlex.europa.eu/legal-content/EN/TXT/PDF/?uri=CELEX: 32003L0051\&from =en>, accessed 19 November 2014.

Council Directive (EC) 2004/109 on the harmonization of transparency requirements in relation to information about issuers whose securities are admitted to trading on a regulated market and amending Directive 2001/34/EC, OJ L 390/38, accessible at <http://eur-lex.europa.eu/LexUriServ/LexUriServ. do? uri=OJ:L:2004:390:0038:0057:EN:PDF>, accessed 19 November 2014.

Council Directive (EC) 2009/29 amending Directive 2003/87/ EC so as to improve and extend the greenhouse gas emission allowance trading scheme of the Community [2009], OJ L 140/63, available at <http://eur-lex.europa.eu/LexUriServ/ LexUriServ.do?uri=OJ:L:2009:140:0063:0087:en:PDF>, accessed 18 November 2014.

Council Directive (EC) 2013/34 on the annual financial statements, consolidated financial statements and related reports of certain types of undertakings, amending Directive 2006/43/ EC of the European Parliament and of the Council and repealing Council Directives 78/660/EEC and 83/349/EEC [2013], OJL 182/19, available at <http://eur-lex.europa.eu/ LexUriServ/LexUriServ.do?uri=OJ:L:2013:182:0019:0076: EN:PDF>, accessed 18 November 2014.

Council Directive (EC) 2014/95 amending Directive 2013/34/ $\mathrm{EU}$ as regards disclosure of non-financial and diversity information by certain large undertakings and groups [2014], OJL 330/1, accessible at <http://eur-lex.europa.eu/legal-content/ $\mathrm{EN} / \mathrm{TXT} / \mathrm{PDF} /$ ?uri=CELEX:32014L0095\&from=EN>, accessed 24 November 2014.

R.H.J. Cox, "The Liability of European States for Climate Change", 30 Utrecht Fournal of International and European Lam 78 , 2014, available at <http://dx.doi.org/10.5334/ujiel. ci>, accessed 17 November 2014, pp. 125-135.

A. Denny Ellerman \& B.K. Buchner, "The European Union Emissions Trading Scheme: Origins, Allocation, and Early Results", Reviem of Environmental Economics and Policy 2007, pp. 66-87.

A.F.M. Dorresteijn et al., European Corporate Lam, Deventer, Kluwer 2009.

V.D. Dragomir, "The disclosure of industrial greenhouse gas emissions: a critical assessment of corporate sustainability reports", Fournal for Cleaner Production, Volumes 29-30, July 2012.

J.H. Dunning \& S.M. Lundan, Multinational Enterprises and the Global Economy, Cheltenham, Edward Elgar Publishing 2008.

European Commission, Public Consultation on Disclosure of NonFinancial Information by Companies, 2010, accessible at $<\mathrm{http}$ ///ec.europa.eu/internal_market/consultations/docs/ 2010/non-financial_reporting/overview_en.pdf>, accessed 19 November 2014.

European Commission, Summary Report Of The Responses Received to the Public Consultation on Disclosure of Non-Financial Information by Companies, April 2011, accessible at $<\mathrm{http}$ ///ec.europa.eu/internal_market/consultations/docs/ 2010/non-financial_reporting/summary_report_en.pdf>, accessed 19 November 2014.

European Commission, Expert Group on Non-Financial Disclosure by Companies - First Meeting, 11 July 2011, available at $<$ http://ec.europa.eu/finance/accounting/docs/11072011_ minutes_en.pdf>, accessed 19 November 2014.

European Commission, Expert Group on Non-Financial Disclosure by Companies - Meeting Report, 30 September 2011, available at <http://ec.europa.eu/internal_market/accounting/docs/ news/30092011-expert-group-minutes_en.pdf $>, \quad$ accessed 19 November 2014.

European Commission, Commission staff morking document accompanying the document Proposal for a Directive of the European Parliament and of The Council as regards disclosure of non-financial and diversity information by certain large companies and groups - Impact assessment, SWD/2013/0127 final, available at <http://eur-lex.europa.eu/legal-content/EN/ALL/?uri= CELEX:52013SC0127>, accessed at 18 November 2014.

European Commission, An Action Plan to Strengthen the Fight Against Tax Fraud and Tax Evasion, COM (2012)/0722 final, available at <http://eur-lex.europa.eu/legal-content/EN/ 
TXT/?uri=CELEX:52012DC0722>, accessed 18 November 2014.

European Commission, A Renemed EU Strategy 2011-14 for Corporate Social Responsibility, COM (2011)/681 final, available at $<$ http://eur-lex.europa.eu/LexUriServ/LexUriServ.do?uri= COM:2011:0681:FIN:EN:PDF>, accessed 18 November 2014.

European Commission, Communication from the Commission to the European Parliament, the Council, the European Economic and Social Committee and the Committee of the Regions Action Plan: European company law and corporate governance - a modern legal framemork for more engaged shareholders and sustainable companies, $\operatorname{COM}(2012) 740 / 2$, available at <http://ec.europa.eu/ internal_market/company/docs/modern/121212_companylaw-corporate-governance-action-plan_en.pdf $>$, accessed on 19 March 2015.

M. Fulton, B.M. Kahn \& C. Sharples, Sustainable Investing: Establishing Long-Term Value and Performance, 2012, available at $<$ http://papers.ssrn.com/sol3/papers.cfm?abstract_id= 2222740>, accessed 18 November 2014.

G20, Policy Statement - Strenghtening tax systems, 2014, available at <www.g20.org/sites/default/files/g20_resources/library/ Tax\%20policy\%20note.pdf $>$, accessed 25 November 2014.

I. Iannou \& G. Serafeim, "The Impact of Corporate Social Responsibility on Investment Recommendations: Analysts' Perceptions and Shifting Institutional Logics", 2013, available at <http://papers.ssrn.com/sol3/papers.cfm?abstract_id= 1507874>, accessed 18 November 2014.

Intergovernmental Panel on Climate Change (IPCC), Special report "Land Use, Land-Use Change and Forestry", R.T. Watson et al. (eds.), Cambridge University Press 2000.

Intergovernmental Panel on Climate Change (IPCC), "Summary for Policymakers", in: Climate Change 2007: The Physical Science Basis. Contribution of Working Group I to the Fourth Assessment Report of the Intergovernmental Panel on Climate Change [S. Solomon, D. Qin, M. Manning, Z. Chen, M. Marquis, K.B. Averyt, M.Tignor \& H.L. Miller (eds.)], Cambridge \& New York, Cambridge University Press 2007, available at <www.ipcc.ch/pdf/assessment-report/ar4/wg1/ar4-wg1spm.pdf>, accessed 18 November 2014.

Intergovernmental Panel on Climate Change (IPCC), Climate Change 2014: Mitigation of Climate Change. Working Group III Contribution to the IPCC 5th Assessment Report [O. Edenhofer, R. Pichs-Madruga, Y. Sokona, E. Farahani, S. Kadner, K. Seyboth, A. Adler, I. Baum, S. Brunner, P. Eickemeier, B. Kriemann, J. Savolainen, S. Schlömer, C. von Stechow, T. Zwickel \& J.C. Minx (eds.)], Cambridge \& New York, Cambridge University Press 2014, available at <http:// www.ipcc.ch/pdf/assessment-report/ar5/wg3/ipcc_wg3_ ar5_full.pdf $>$, accessed 18 November 2014.

S. Ivanjko, M. Kocbek \& S. Preliç, Korporacijsko pravo, Ljubljana, GV Zalozba 2009.

R.E. Kraakman et al., The Anatomy of Corporate Law: A Comparative and Functional Approach, Oxford, Oxford University Press 2009.

T.E. Lambooy, "Sustainability Reporting by Companies is Necessary for Sustainable Globalisation", in E.C. Nieuwenhuys (ed.), Neo-Liberal Globalism and Social Sustainable Globalisation, Leiden-Boston, Brill 2006.

T.E. Lambooy, Corporate Social Responsibility. Legal and semilegal framemorks supporting CSR, Deventer, Kluwer 2010.

T.E. Lambooy, A. Argirou \& M. Varner, "Oil Companies and Effective Remedies: Can Ruggie's Guiding Principles Help?", in S. Deva \& D. Bilchitz (eds.), Human Rights Obligations of Business: Beyond Corporate Responsibility to Respect, Cambridge, Cambridge University Press 2013.

T.E. Lambooy et al., "The Opacity of a Multinational Company's Organization, Legal Structure and Power. What Type of
Corporate Information Must a Multinational Company Make Public Pursuant to Dutch law? Options for Improving Dutch Law: Better Access to Corporate Information for Stakeholders", The Dovenschmidt Quarterly 2013, pp. 121-133.

T.E. Lambooy, R.A. Diepeveen \& S. van 't Foort, "Corporate Social Responsibility and Transparency: How Could We Amend Dutch Law to Improve Transparency with Regard to Dutch Multinational Companies? Conference Report CSR Workshop, 17th Annual Ius Commune Conference, 29 November 2012, Amsterdam", International and Comparative Corporate Lam Journal 2013.

J. Mähönen \& C. Villiers, "Accounting and Reporting standards", in B. Sjåfjell \& B.J.Richardson (eds.), Company Law and Sustainability, Cambridge, Cambridge University Press 2015 (forthcoming).

B. McKern (ed.), Managing Global Network Corporation, London, Routledge 2003.

P.T. Muchlinski, Multinational Enterprises and the Lam, Oxford, Oxford University Press 2007.

E. Muzaffer, Multinational Enterprises and Tort Liabilities, Cheltenham, Edward Elgar Publishing 2008.

A.E. Oderkerk, "The Need for a Methodological Framework for Comparative Legal Research: Sense and Nonsense of 'Methodological Pluralism' in Comparative Law”, CSECL Working Paper Series, 2014, available at SSRN: <http://ssrn.com/ abstract $=2422265>$, pp. $1-38$.

Organisation for Economic Cooperation and Development (OECD), OECD Guidelines for Multinational Enterprises, 2011, available at <www.oecd.org/corporate/mne/>, accessed 18 November 2014.

Organisation for Economic Cooperation and Development (OECD), Tackling Aggressive Tax Planning Through Improved Transparency and Disclosure, 1 February 2011, available at $<$ www.oecd.org/tax/exchange-of-tax-information/48322860. pdf $>$, accessed 18 November 2014.

Organisation for Economic Cooperation and Development (OECD), Corporate Loss Utilisation Through Aggressive Tax Planning, August 2011, available at <http://browse. oecdbookshop.org/oecd/pdfs/product/2311471e.pdf>, accessed 18 November 2014.

Organisation for Economic Cooperation and Development (OECD), Hybrid Mismatch Arrangements, March 2012, available at <www.oecd.org/tax/aggressive/HYBRIDS_ENG_ Final_October2012.pdf $>$, accessed 18 November 2014.

Organisation for Economic Cooperation and Development (OECD), Addressing Base Erosion and Profit Shifting, February 2013, available at <www.keepeek.com/Digital-AssetManagement/oecd/taxation/addressing-base-erosion-andprofit-shifting_9789264192744-en\#page1>, accessed 18 November 2014.

E. Örücü, "Methodological Aspects of Comparative Law", 8 Eur. 7.L. Reform 29, 2006, pp. 29-42.

M.E. Porter \& M.R. Kramer. "Strategy and Society: The Link between Competitive Advantage and Corporate Social Responsibility", 84 Harvard Business Reviem 12, 2006.

J. Peel, "The Australian Carbon Pricing Mechanism: Promise and Pitfalls on the Pathway to a Clean Energy Future", 15 Mississippi Fournal of Law, Science E Technology 1, 2014, pp. $429-468$.

PricewaterhouseCoopers (PwC), Exploring Emerging Risks, 2009, available at $<$ www.pwc.nl/nl/publicaties/exploring-emerging -risks.jhtml>, accessed 18 November 2014.

T.P. van Reenen, "Major Theoretical Problems of Modem Comparative Legal Methodology (1): The Nature and Role of the Tertium Comparationis", 28 Comp. ES Int'l L.F. S. Afr. 407, 1995, pp. 407-421.

J.F. Robe, "The Legal Structure of the Firm", 1 Accounting, Economics, and Law 1, 2011, available at <www.degruyter.com/ 
view/j/ael.2011.1.1/ael.2011.1.1.1001/ael.2011.1.1.1001. xml>, accessed 17 November 2014, pp. 1-88.

J.E. Stiglitz, Address to panel on Defending Human Rights, UN Business \& Human Rights Forum Geneva, 3 December 2013, available at <www.ohchr.org/EN/Issues/Business/Forum/ Pages/2013FBHRSubmissions.aspx $>$, accessed 18 November 2014.

J. Tonello, What Board Members Should Know About Communicating CSR, 2011, available at <http://blogs.law.harvard.edu/ corpgov/2011/04/26/what-board-members-should-knowabout-communicating-corporate-social-responsibility/>, accessed 18 November 2014.

United Nations Conference on Trade and Development (UNCTAD), World Investment Report 2011, 2011, available at $<$ http://unctad.org/en/PublicationsLibrary/wir2011_en. pdf $>$, accessed 18 November 2014.

United Nations Conference on Trade and Development (UNCTAD), Investment and Enterprise Responsibility Reviem, 2011, available at $<$ http://unctad.org/en/docs/diaeed20101_ en.pdf>, accessed 24 November 2014.

United Nations Environment Partners (UNEP), KPMG \& GRI, Carrots and Sticks: Promoting Transparency and Sustainability: An update on trends in Voluntary and Mandatory Approaches to Sustainability Reporting, 2010, available at <www.unep.fr/ shared/publications/pdf/WEBx0161xPA-Carrots\%20\& \%20Sticks\%20II.pdf>, accessed 18 November 2014.

K. Vandekerckhove, Piercing the Corporate Veil, Alphen aan den Rijn, Kluwer Law International 2007.

A. Vlachou, "The European Union's Emissions Trading System”, Cambridge Fournal of Economics, 2013, pp. 1-26.

A.L. Vytopil, "Contractual Control and Labour-Related CSR Norms in the Supply Chain: Dutch Best Practices", Utrecht Law Reviem, 2012, pp. 155-169.

E. Weitzenboeck, A Legal Framemork for Emerging Business Models: Dynamic Netmorks as Collaborative Contracts, Cheltenham, Edward Elgar Publishing 2012.

K. Zweigert \& H. Kötz, Introduction to Comparative Lam, Oxford, Oxford University Press 1998.

K. Zweigert, "Zur Methode der Rechtsvergleichung", 13 Zeitschrift für interdisziplinäre Studien 4, 1960, pp.193-200.

\section{News-item}

C. Osgood, J. Rue \& J. Kho, "Business Structures and Sustainability: How Are They Connected?", The Guardian, London, 21 November 2013, available at <www.theguardian.com/ sustainable-business/interactive/business-structuressustainability-connection-interactive>, accessed 17 November 2014. 